\title{
Physiology of energy homeostasis: models, actors, challenges and the glucoadipostatic
} loop

Didier Chapelot ${ }^{1}$, Keyne Charlot $^{2}$

${ }^{1}$ Université Paris 13, Centre de Recherche en Epidémiologie et Statistique, Equipe de Recherche en Epidémiologie Nutritionnelle (EREN), Inserm (U1153), Inra (U1125), Cnam, Université Paris 13, Bobigny, France

${ }^{2}$ Institut de Recherche Biomédicale des Armées, Unité de Physiologie des Exercices et Activités en Conditions Extrêmes, Département Environnements Opérationnels, Brétignysur-Orge, France

Corresponding author

Didier Chapelot

UFR Santé Médecine \& Biologie Humaine, 74 rue Marcel Cachin, 93017, Bobigny, France Telephone: +33148387736

E.mail: chapelot@univ-paris13.fr 


\section{Abbreviations}

AgRP, agouti-related peptide; BSS, behavioral satiety sequence; AMPK, AMP-activated protein kinase; ARC, arcuate nucleus; BDNF, brain-derived neurotrophic factor, CART, cocaine and amphetamine regulated transcript; CCK, cholecystokinin; CfD, cafeteria diet; CNS, central nervous system; DIO, diet-induced obesity; DIWL, diet-induced weight loss; $\mathrm{DMH}$, dorsomedian nucleus; DMV, dorsal motor nucleus of the vagus; DR, diet resistant; $E B$, energy balance; $E E$, exergy expenditure; $E H$, energy homeostasis; El, energy intake, EIEE, exercise-induced energy expenditure; FFA, free-fatty acids; GLP-1, glucagon-like peptide 1; IMI, intermeal interval; $\mathrm{LH}$, lateral hypothalamus; $\mathrm{MCH}$, melanin concentratin hormone; NPY, neuropeptide Y; NEAT, non-exercise activity thermogenesis; nREE, non-resting energy expenditure; NAcc, nucleus accumbens; NTS, nucleus tractus solitarius; OXM, oxyntomodulin PAL, physical activity level; POMC, pro-opiomelanocortin; PP, pancreatic polypeptide; PPGD, preprandial glucose decline; PVN, paraventricular nucleus; REE, resting energy expenditure; SCN, suprachiasmatic nucleus; SNS, sympathetic nervous system; SPA, spontaneous physical activity; SF-1, steroidogenic factor 1; TEE, total energy expenditure; $\mathrm{VMH}$, ventro-medial hypothalamus; VTA, ventral tegmental area; WAT, white adipose tissue. 


\section{Abstract}

The aim of this review is to discuss the physiology of energy homeostasis (EH), which is a debated concept. Thus, we will see that the set-point theory is highly challenged and that other models integrating an anticipative component, such as energy allostasis, seem more relevant to experimental reports and life preservation. Moreover, the current obesity epidemic suggests that $\mathrm{EH}$ is poorly efficient in the modern human dietary environment. Non-homeostatic phenomena linked to hedonism and reward seem to profoundly impair EH. In this review, the apparent failed homeostatic responses to energy challenges such as exercise, cafeteria diet, overfeeding and diet-induced weight loss, as well as their putative determinants, are analyzed to highlight the mechanisms of $\mathrm{EH}$. Then, the hormonal, neuronal, and metabolic factors of energy intake or energy expenditure are briefly presented. Last, this review focuses on the contributions of two of the most pivotal and often overlooked determinants of EH: the availability of endogenous energy and the pattern of energy intake. A glucoadipostatic loop model is finally proposed to link energy stored in adipose tissue to $\mathrm{EH}$ through changes in eating behavior via leptin and sympathetic nervous system activity. 


\section{Introduction}

Homeostasis is the tendency of an organism to maintain a stable internal state. It is a more neutral and descriptive concept than control or regulation [1], that need to determine the operator and the regulated value [2] to achieve balance. In the case of energy homeostasis $(\mathrm{EH})$, this supposes that the energy balance (EB) between the energy supplied and dissipated is stable. For some authors, this means that energy stores are kept constant throughout the lifespan. The worldwide epidemic of increased obesity in humans [3] shows that this is not the case, at least during the dynamic phase. Actually, EH is often used to describe the mechanism by which an organism not only fulfills its energy needs, but also reduces or induces input (intake) when output (expenditure) decreases or increases, respectively. If energy needs are efficiently supplied when environmental conditions are appropriate, experimental and epidemiological data show that the reduction of energy intake (EI) is not sufficient to preclude increased energy storage when energy expenditure (EE) is low e.g., low physical activity level (PAL), leading to fat deposition and obesity. Mechanisms of EH seem to be poorly efficient against excessive El in individuals [4]. One hypothesis is that in certain dietary environments and with certain behaviors, excess El relative to total EE (TEE) is necessary to maintain energy supply due to impaired mobilization of energy stores.

In the concepts of homeostasis by Claude Bernard [5] or Walter Cannon [6] there was the notion than outside of a given interval of stability, life was not possible. Neither of them imagined a fixed programmed value but only a response adapted to an external stimulus [7]. However, homeostasis was reactive and not anticipative. Most of the models were based on the satisfaction of basic needs, such that the response of the organism to the low availability of a specific need for an "element" resulted in the stability of the dependent body variables, either by a behavioral (research of the required "element") or physiological (cascade of effects leading to the compensation of this missing "element") response. The opposite was expected when the "element" was provided in excess. This theory is now challenged, supporting a large excess of El without apparent behavioral or physiological responses leading a large proportion of humans, notably in recent history, to store much more energy than they need. This may either be interpreted as a failed $\mathrm{EH}$ or maybe it is an incorrect understanding of what is $\mathrm{EH}$. It must be remembered that overweight and obesity conditions did not exert any negative selective pressure on humanity during most its history. 


\section{Modelizing and discussing energy homeostasis}

\subsection{Input and output of energy homeostasis}

EH must not be represented by a simple input / output model. Between the two lies a very flexible energy storage compartment which is the target of many physiological factors (Figure 1). A long history of experimental studies conducted in animal models has explored these factors. In rats confined in a laboratory or in animals and humans during growth, more than homeostasis, we should use the term homeorhesis [8], the phenomenon by which the internal state is maintained, not in the initial state but in the state of its normal trajectory through time. Control groups of rats usually gain weight and fat mass during the experimental periods. Thus, when the interventional groups are compared to their control pairs to determine whether homeostasis occurred, what is tested is not homeostasis per se, but homeorhesis.

\subsection{The set-point theory}

The set point theory [9] supposes that a regulated hypothalamic body weight or white adipose tissue (WAT) mass would be defended against voluntary (e.g., dieting) or involuntary (e.g., fluctuating availability or composition of food) changes. This would make EH an ancillary mechanism to fat mass regulation as proposed by Kennedy [10] in his lipostatic model. He proposed that fat mass was regulated at the hypothalamic levels so that it remains constant in varied environmental conditions and provides the necessary energy substrates. Kennedy was the first to link adipose tissue (called "fat depots") to satiety. This was an innovative and promising concept that was even interpreted as the existence of a adipocyte-derived factor acting on eating behavior [11]. The theory would be confirmed several years later, notably with the discovery of leptin. This direct afferent link was demonstrated with the observation that adipocyte size may alter food intake [12]. However, the results of surgical lipectomy have challenged the theory that fat mass was tightly regulated, showing that fat pads restoration displayed large variations according to their localization [13] and to the composition of provided food, being only effective with a high-fat diet [14]. Interestingly, leptin is not involved in this restored process [15]. The restoration of fat mass after lipectomy was hypothesized to be the consequence of reduced sympathetic nervous system (SNS) activity and consecutive reduction in TEE and lipolysis more than increased EI [16]. Importantly, another lipostatic approach was proposed by Jacques Le 
Magnen, based on the fatty acid utilization during the rest period (daytime in rats) of the fatty acids stored during the active period (nighttime in rats) [17]. Overeating in the active period was associated with increased fat synthesis and followed by reduced food intake and increased lipolysis in the rest period. Therefore, a more flexible metabolic model was therefore proposed and experimentally supported [18], in which fat mass stabilization was achieved when the mean respiratory quotient reached the mean food quotient i.e., the proportions of fat and carbohydrate metabolized by the organism reached those in the diet. Thus, more than energy per se, the macronutrient content and individual potential oxidative capacities, would be a prerequisite for accurate EH. EH could be considered as a stochastic value with some possibility to be predicted with an expected accuracy if enough determinants are known. The major challenge to date is to accumulate the exhaustive inventory of these determinants. Although the set point theory is strongly contested $[2,7]$ to this date it is a theoretical framework used by many authors [19].

\subsection{Alternative models to homeostasis}

One hypothesis is that $\mathrm{EH}$ is not centered on the stability of energy stores or the equilibrium between energy needed and supplied, but on the availability of energy over the various periods of energy disposal during the circadian cycle. This would explain why some dietary or sedentary habits lead to apparently inconsistent El, and an excess of energy stored in the form of fat mass, due to a weak stimulation of fatty acid disposal. The allostasis concept in which the body "anticipates needs and prepares to satisfy them before they arise" [20] seems to fit more to observations in the domain of EH. A predictive model [21], in opposition to a reactive model, is not only better adapted to the irregular availability of energy substrates, but avoids the unpleasant consequences of energy deficit such as prolonged hunger [22]. It has been shown that rats adapt to meal omission by rapidly switching from a reactive (increase of the next meal size) to an anticipatory (increase of the previous meal size) strategy when conditioning is possible using external e.g., time of day [23] or nutritional, e.g., odor or savor [24] cues. Thus, food intake, and therefore EH, must be considered as Pavlovian conditioning [25] with sensory characteristics of foods and the environmental cues associated with food intake, as conditioning factors. To this day, most of the models of $\mathrm{EH}$ are unfortunately based on a response to a shortage of energy and not to 
cues signaling a necessary anticipatory behavior. Moreover, the behavioral components of EI are too much overlooked.

\subsection{The role of pattern of energy intake in energy homeostasis}

Energy exchanges are not a continuous but a sequential process. If TEE is relatively constant on a daily scale, bouts of $E E$, most often due to physical activity, are however spread during the circadian cycle. Similarly, energy is provided through macronutrients in the form of food in a specific entity called a meal. A meal is not simply an eating period, but has several temporal, behavioral and even biological characteristics (see below, in the Glucose section). In rats, a behavioral satiety sequence (BSS) is even used to define a meal [26]. Some authors have defined non-meal eating (snacks) as having some missing criteria of the BSS [27]. In humans, meals are most often defined on purely cultural criteria (breakfast, lunch, dinner) and snacks as intermeal eating, but some biological and behavioral characteristics have been proposed such as initiating eating with a low or no-hunger feeling [28]. For heuristical purposes, a meal should be considered as a physiological process of energy supply. There are some reasons to suspect that snacks contribute to excess El and may impair EH [29]. When eating in the absence of hunger (EAH) was studied, it was positively associated with weight gain in adolescents [30] and normal-weight women [31]. The supposed benefit of snacking on satiety and $\mathrm{EH}[32,33]$ uses the social or quantitative definition of snacks, confusing the putative benefits of meal frequency with snacks [34]. According to definitions used for snacks, their effects on EH are discrepant [35]. Our team has repeatedly found that snacks, defined as eating in a no-hunger state, exerted poor satiety effects and were not compensated for at the next meal and therefore added extra-energy to total EI $[28,36,37]$. However, the consequence on 24-h EB is not known. Since conditioning on an arbitrary cue can trigger eating [38], it is possible that permanent food solicitation may initiate EAH.

In free meal conditions, El response to varying availability or energy content of food, occurs mainly through the modification of intermeal intervals (IMI) and not meal size [39]. Thus, satiety (duration of the IMI) and not satiation (size of the meal), seems to be the main component of El involved in $\mathrm{EH}$ [40]. This role in the homeostatic response to diets inducing obesity has been highlighted in a study where after a phase of weight gain, rats fed a highly palatable diet decreased their eating frequency that became much lower than in rats maintained on chow [41]. This was shown in diet-induced obesity (DIO) compared to diet 
resistant (DR) or chow fed rats [42], and further confirmed when separating meals and snacks based on BSS characteristics, with a decrease in meal but not snack frequency [27]. Similarly, in humans, switching from 4 to 3 meals per day led to increased fat mass after 30 days [43], confirming that longer IMI (lower meal frequency) is rapidly associated with higher fat mass. This confirmed older studies conducted in free-living conditions showing that children switched on a low meal frequency increased their fat mass compared to children on a high meal frequency [44]. Moreover, individuals with a high meal frequency showed a reduced risk of obesity [45] an improved efficiency in adapting El to manipulation of foods and maintaining EH [46]. The supposed fat mass-increasing effect of high eating frequency, for example in postmenopausal women [47], is based (and biased) on a definition of eating not discriminating between meals and snacks (any drink, sugar-containing or not, consumed without any food was even considered as an eating episode). Moreover, in randomized controlled trials comparing eating frequency, eating episodes are not defined [48].

In rats, it was demonstrated that during the passive period, animals used fatty acids stored during the active period to delay IMI and therefore reduce meal frequency [17]. In humans, spontaneous initiation of meals is a prerequisite to explore the role of eating patterns in EI and $\mathrm{EH}$. Using this procedure, our team has found that dietary $[49,50]$ and pharmacological [51] interventions that enhance fat availability to metabolism, increased satiety i.e., length of the IMI. The mechanism would involve the sparing-glucose effect of fat oxidation [52], known as the Randle cycle $[53,54]$, that may delay the next meal onset. However, the ratio between the oxidized proportion of dietary fat and the increase in IMI is small [49], leading to fat storage [55].

\section{A brief description of the actors involved in energy homeostasis}

Multiple substrates, hormones, neurotransmitters and brain neurons [56] were found to exert an action on $\mathrm{EH}$ through their effects on $\mathrm{EI}$ and/or $\mathrm{EE}$, and new molecules are constantly discovered [57]. An exhaustive analysis and discussion of their putative involvement in $\mathrm{EH}$ would exceed the authorized length of this review. However, it is important to schematically distinguish six components (Figure 2).

The first component is the beam of afferent hormones and neurons linking the peripheral system to the CNS [58]. Most studied were 1) the adipokines leptin [59] and adiponectin [60], 2) the pancreatic hormones insulin [61], amylin [62] and pancreatic polypeptide 
(PP)[63], 3) gut hormones such as the anorexigenic cholecystokinin (CCK), glucagon-like peptide 1 (GLP-1), oxyntomodulin, peptide tyrosine tyrosine (PYY) [64-66], and the orexigenic ghrelin [67], and 4) the vagal neurons [68].

The second component is the hypothalamus, the brain area where peripheral messages induce homeostatic responses altering $\mathrm{EI}$ and $\mathrm{EE}[69,70]$. Most of the afferent pathways converge on the arcuate nucleus (ARC) where are localized neurons synthetizing the orexigenic neuropeptide $\mathrm{Y}$ (NPY) and agouti-related peptide (AgRP) as well as the anorexigenic pro-opiomelanocortin (POMC)-derived $\alpha$ melanin stimulating hormone ( $\alpha \mathrm{MSH})$ and cocaine and amphetamine regulated transcript (CART)[71]. Projections are sent 1) from the NPY/AgRP neurons to NPY receptors (NPY1, NPY2 and NPY5) in the orexin and melaninconcentrating hormone $(\mathrm{MCH})$ neurons of the lateral hypothalamus (LH) leading to increased $\mathrm{El}$, and 2) from the POMC/CART neurons to the melanocortin receptors (MC3R/MC4R) localized on the paraventricular nucleus (PVN) leading to decreased El. Moreover, AgRP acts as a natural antagonist of MC3R and MC4R, inhibiting the orexigenic action of $\alpha \mathrm{MSH}$ [72]. Other target of the POMC/CART neurons is the ventromedial hypothalamic nucleus (VMH), activating neurons synthetizing the anorexigenic brain-derived neurotrophic factor (BDNF) [73]. The VMH also exerts a potent stimulating effect on SNS activity [74].

The third component is the brainstem and notably the nucleus tractus solitarius (NTS), receiving contributing to reduced El through the interaction between leptin and gut hormones (e.g., GLP-1) with AMPK as intermediate, [75] integrating blood-borne and vagal mediated messages from periphery [76].

The fourth component is the reward system consisting of: 1) the mesolimbic dopamine system and more specifically the ventral tegmental area (VTA) and the nucleus accumbens (NACC), where schematically the hedonic and reward response to eating are established based on previous experiences [77], and 2) the opioid system in specific subregions of the ventral pallidum (VP)[78] and the NAcc (the hotspots) [79], specifically involved in the reward of highly palatable food [80] and the support of the "liking" versus "wanting" theory [81] according to the implication of the hedonic component in the reward-induced motivations to eat [82]. Lastly, the amygdala, through its connection with the LH, is crucial for conditioning processes i.e., associating food to cues [83]. 
The fifth component is the cognitive frontal and cortical system, notably the prefrontal cortex (PFC) and anterior cingulate cortex (ACC) [84], involved in decision making, self-control and executive functions that were found to differ between non obese and obese status of the individuals [85].

All of these brain areas are highly interconnected [82] and $\mathrm{EH}$ must be considered as resulting from an integrative process involving all of these aforementioned brain and peripheral actors [84]. For example, ghrelin [86] and amylin [87] have been shown to interact with the dopamine mesolimbic system.

The sixth component, often overshadowed by the directly altered El effect of these factors, is the neuronal efferent pathway represented by the SNS. This is all the more important since as we will see, its role exceeds the modulation of EE but may also strongly influence the effects of all the previous factors on El [88].

\section{Energy homeostasis challenges}

Conditions challenging EH represent potential sources of knowledge about its mechanism of action. Among them, four are particularly interesting due to their relevance to contemporary situations in humans.

\subsection{Exercise}

Studies showed that when shifted from inactivity to exercise on a treadmill, rats did not increase their El but decreased it and lost weight [89], thus challenging the concept of EH. It was not before reaching 60 min of daily exercise that El reached a higher level than when they were inactive [90]. The homeostasis interval was estimated between 1.7-1.8 and $2.2 \mathrm{x}$ REE [91]. These results raise two complementary interpretations: 1) "no-exercise" leads to a positive energy balance resulting in gain weight, and 2) under a certain volume of activity, exercise-induced energy expenditure (EIEE) is not compensated. The possible contribution of low PAL to human obesity [92,93] has received some support and is consistent with the hypothesis that under a threshold level of PAL, EH is impaired.

In obesity, exercise induces only modest weight-loss [94] but results in a decrease in fat mass and an increase in fat-free mass [95], showing the mobilization of energy stored in the WAT. Considering the role of exercise in EH only through the consequences on EE is erroneous. Although even in very active individuals EIEE may only account for 15 to $30 \%$ of TEE [96,97], 
exercise leads to profound metabolic changes [98] that alter substrate metabolic partitioning between oxidation and storage [99]. One mechanism of these exercise-induced benefits in EH would actually be through its effects on TEE [100] and free fatty acid (FFA) release from the WAT [101], both being potentially mediated by SNS activity [102] leading to increased fat oxidation as soon as in the post-exercise period [103].

As in rats, EIEE is weakly compensated in humans $[104,105]$ at least in the short-term. The mechanisms of this absence of efficient energy compensation is still unclear but the involvement of gut peptides, specially GLP-1, PP and PYY [106] and also acylated ghrelin $[107,108]$ have received some experimental support. Importantly, when individuals are free to initiate their meal following an exercise session, an increased IMI has been reported [109111]. The post-exercise increase in FFA disposal may contribute to this effect [112] notably through increased SNS activity during exercise [113] and an improved catecholamine response in the WAT [114].

\subsection{Cafeteria and high-fat diets}

The fact that rats can drastically increase their El without apparent need and become obese when either high-fat [115] or highly varied, palatable and high-energy density foods [116] are provided i.e., cafeteria diet (CfD), suggests that EH can be easily overridden with a simple modification of dietary environment. This excess El and consequent body weight gain greatly varies both across strains [117] and between substrains [118] of rats, some showing no tendency to overeat and to gain weight (illustrating accurate EH) whereas others showing various levels of gain weight, some reaching high level of obesity (illustrating failed EH). Interestingly, variety constantly leads to weight gain whereas less varied but high-fat diets produce obesity only in DIO rats [119]. High-energy density of the CfD is not the culprit since variety with low-energy density foods can yield a similar and even greater level of overeating and weight gain [120-122]. The increased El effect of variety has been verified in human studies $[123,124]$ and may represent a major factor of failed EH and obesity [125]. This has led some authors [126] to propose that El is not only driven by homeostatic but also by nonhomeostatic mechanisms, mainly related to hedonism and reward [127]. The eating triggering-power of the environment is a potential disturbance factor, free choice being one of the main causal factors of the obesogenic power of a high energy-density diet [128]. These results indicate that $\mathrm{EH}$ is easily impaired or, more neutrally, switched to a new 
equilibrium, by dietary conditions such as variety and palatability. This supports the potential role of the hedonic reward system to alter EH toward a non-homeostatic El [127]. Interestingly, when metabolic characteristics of DIO compared to DR rats were analyzed, the most often reported results were a reduced SNS activity and a lower efficiency to oxidize fat [129], associated with increased insulin levels [130]. This difference in the capacity to oxidize dietary and stored fats in rats is in common with human diet induced obesity [18].

\subsection{Overfeeding}

A recent systematic review [131] concluded that overfeeding leads to a 7 to $18 \%$ increase in TEE, allowing $\sim 25 \%$ of excess energy to be dissipated [132]. This suggests that the efficiency for EE to realize EH is limited. Among the components of TEE, REE represented only a small part ( one fourth) of overfeeding-induced increase [132]. EIEE was reported to display 38 to $50 \%$ of the increase in EE [132-134], integrating spontaneous physical activity (SPA) as a potent actor of EH. Non-exercise activity thermogenesis (NEAT), such as fidgeting, posture, and the physical activities of daily life, represented the largest part of the increased EE and was found to be closely linked to overfeeding-induced fat storage [133]. No reduction in EI was observed during the days following an overfeeding period $[134,135]$. However, in real life conditions, when subjects are back in their pre-overfed dietary environment, they return to their initial body weight after several months [136]. It is not known whether this is the consequence of a physiological process or of the complex interaction between social, cultural and biological parameters. Moreover, age seems crucial since young ( 24 yr) but not elderly ( 70 yr) men were reported to lose all the accumulated weight gain during the overfeeding period after 46 days [137]. On the mechanistic side, SNS activity has again been proposed as the candidate to explain differences in altered EH [138], limiting energy storage in increasing EE.

\subsection{Weight-loss}

Relapses after diet-induced weight loss (DIWL) are relatively frequent ( $50 \%$ at year 1 ) $[139,140]$. Factors leading to weight regain are beginning to be clearly determined including: decreased PAL, increased percentage of dietary fat, and dietary disinhibition [141-143]. The reduction in REE after DIWL strongly depends on the type of tissue lost i.e., decreased energy needs if more fat-free mass is lost, but is constantly higher than that predicted by 
tissue loss. Called adaptative thermogenesis, this phenomenon represents a factor limiting further weight loss [144], explaining $~ 50 \%$ of the less than expected weight loss results [145]. In a study [146], 10\% of body weight lost in lean and obese individuals obtained with a low-energy diet, was associated with a 10 to $15 \%$ decline in REE. The proportion of fat mass lost showed a high variability between individuals and between initial BMI categories e.g., $63.7 \pm 27.5 \%$ and $83.6 \pm 23.8 \%$ in lean and obese subjects, respectively [146]. This was associated with a $20 \%$ increase in skeletal muscle work efficiency that could account for $\sim 75 \%$ of the decline in non REE [147]. There are various causative factors: a decrease in the glycolytic to oxidative enzyme activity ratio [148], a change in muscle fiber structure [149] and a decrease of SNS activity [150]. The higher than expected reduction in TEE after a DIWL would have no impact on regain if El decreased accordingly. However, an increased motivation to eat was described using subjective (questionnaires) and objective (meal intake) tools after a $10 \%$ body weight reduction [151]. Excessive El relative to energy needs after DIWL suggests that the energy consumed to maintain body weight is not sufficient to preclude an activation of the orexigenic system. With eating behavior being subjected to a learning process linking El to the post-prandial effects and energy needs [24,152], the conditions are therefore not fulfilled for a satisfying flux of energy precluding the body to search for more energy. Allowing El mechanisms of EH to operate seems to be important, since an ad libitum low-fat diet leads to an improved maintenance of DIWL compared to a fixed energy similar diet [153]. Interestingly, exercise has been shown to improve maintenance of weight loss $[154,155]$ in increasing EE but also in changing substrate partitioning in favor of fat oxidation [156].

\section{The glucoadipostatic loop}

From the various results reported after previously described EH challenges, it appears that the capacities for stored or consumed fatty acids to reenter in the oxidative cycle is crucial to preventing weight gain. The main determinants of these capacities are the SNS, glucose, insulin and leptin. To be exhaustive, the role of some intestinal hormones will be briefly summarized and the influence of the circadian rhythmicity.

\subsection{Sympathetic nervous system}


The role of SNS activity in EH is well known [157] and its dense and heavily interconnected network with brain areas such as the ARC, the $\mathrm{VMH}$ and the $\mathrm{DMH}$ has been extensively described [158]. Importantly, WAT receives SNS innervation from the CNS [159] that increases adipocytes lipolysis [160] and inhibits fat cell proliferation [161]. Visceral and subcutaneous adipose tissues do not completely share the same circuitry [162]. SNS activity has been implicated in the impaired EH associated with obesity [163]. Low muscle [164] and total [165] SNS activity was proposed as a risk factor to developing obesity on a westernized diet after studying the weight gain outcomes in Pima Indians. This led to the MONA LISA (for Most Obesities kNown Are Low In Sympathetic Activity) theory [166]. Once obesity is established [167] or even after modest weight gain [168], muscle sympathetic nervous system (MSNS) activity is higher but WAT SNS activity is lower [169], potentially reducing lipolysis and fatty acid release [170] for supplying energy needs. This may contribute to the apparent discrepancy between El and energy stores, the latter being not available at the predicted level due to low adipose SNS activity and high insulin levels. Moreover, SNS activity reduces glucose-induced insulin secretion [171] and this action has been considered the onset of metabolic deleterious consequences of the decreased SNS activity induced by high-fat diets [172].

\subsection{Glucose}

The contribution of glucose to $\mathrm{EH}$ has been proposed by Mayer [173] in the conceptual framework of the glucostatic theory, making this energy substrate the main intermediate of the short-term EH in triggering meal onset. This was given experimental support in rats [174] and in humans [175], each meal being preceded by a short preprandial glucose decline (PPGD) [176]. A PPGD was shown to discriminate between meals (El motivated by hunger) and snacks (El initiated with low or no hunger feeling) [28]. Thus, glucose is a satiety and not a satiation factor in the sense that it is involved in initiating and not in terminating a meal. The more this PPGD will be postponed, for example by fat oxidation, the longer will be the duration of the IMI as it was demonstrated with various dietary or pharmacological interventions $[49,51]$.

The involvement of glucose in the different areas of the brain controlling energy is ubiquitous. In a classic paper, Oomura et al. [177] reported that in the LH, neurons could be inhibited by glucose (GI neurons) and that in the VMH, neurons showed a dose-dependent 
increased excitation in response to glucose (GE neurons) [178]. The role of these GI and GE neurons on food intake was rapidly documented in rats and monkeys $[179,180]$. In the ARC, orexigenic NPY/AgRP neurons were found to be GI neurons [181] whereas anorexigenic POMC/CART neurons were found to be GE neurons [182]. Consistently, GE neuron activity is inhibited by orexigenic neurotransmitters (NPY, orexins) [183] and stimulated by anorexigenic neurotransmitters (POMC, $\alpha-M S H)$ [184]. Importantly, the VMH contains GE and GI neurons [185] and it was shown that food intake was associated with an increased glucose level in the VMH [186]. Thus, consistent with the glucostatic theory, glucose appears to be a pivotal modulator of the action of factors from the afferent pathways in orexigenic and anorexigenic neurotransmitter synthesis and action [187]. For example, orexin synthesis requires a fall in plasma glucose [188]. The actions of glucose-sensing neurons needs the intermediate of glucokinase [189] and the metabolic sensor AMP-activated protein kinase (AMPK) [190]. Moreover, glucose is a potent activator of EE through its effect on the beta-1 adrenergic receptor of the SNS [191]. An impaired glucose response in the hypothalamus has actually been established in DIO rats [192] and obese humans [193].

One hypothesis is that glucose modulates the action of the peripheral actors on the brain areas in charge of $\mathrm{EH}$, with regard of the required concentrations of glucose in the blood. Since it does not completely overlap with the glucostatic theory, it has been renamed the glucoadipostatic hypothesis [194]. In a holistic perspective, it is reasonable to hypothesize that the presence of glucose in the integration of messages provided by multiple neurohormonal actors, would represent a safety system for the body.

\subsection{Leptin}

The role of the adipokine hormone leptin in $\mathrm{EH}$ is relatively complex [59]. Since its administration reduces body weight and more specifically fat mass via decreased food intake, it was considered as regulating WAT [195] and called a "satiety" factor [196]. An effect on satiety should mean an increased length between meals and not a reduced meal size. This was confirmed in a study comparing leptin and fenfluramine [197]. Leptin is the main actor of an afferent path linking WAT and the brain, in particular the hypothalamic areas involved in food intake and EE [198-200]. In EH terms, leptin may serve as a hormonal factor leading the body to rely more on stored energy and less on El. In this mechanistic mode, any change in El or EE would be followed by an opposite change driven by leptin to 
maintain a null EB. Fat mass increases leptin levels and will have two complementary and consistent actions in the CNS: 1) to decrease exogenous sources (food intake) and 2) to increase endogenous sources of energy.

Targets and circuitry for the action of leptin on food intake in the CNS are partially known. In the ARC, leptin stimulates anorexigenic POMC and CART expression [201] and inhibits orexigenic NPY and AgRP expression [202]. In the LH, leptin inhibits orexigenic orexin [203]. In the $\mathrm{VMH}$, leptin activates steroidogenic factor 1 (SF-1) and reduces the orexigenic effect of a high-fat diet [204]. In the NTS, leptin acts synergistically with GLP-1 and CCK to decrease food intake [205]. In the mesolimbic dopamine system and in particular the VTA [206-209], leptin decreases the hedonic response to foods in rats [210] and in humans [211], adding a role of this hormone in the increased-intake effect of food palatability. Lastly, via its inhibiting action on orexin, a neurotransmitter that stimulates arousal, alertness and locomotor activity [212], leptin also modulates SPA. These actions on VTA and orexins were shown to be interrelated and contribute to $\mathrm{EH}[213]$.

The mechanism for increasing endogenous sources of energy is less well established. Leptin leads to increased FFA release from WAT possibly via a direct action on adipocytes [69] but much more importantly by increasing SNS activity $[170,214]$ in the ARC [215]. This increased adipocyte lipolysis is also mediated by its direct [216] and SNS-induced [217] inhibitory effect on insulin secretion, demonstrated with changes in physiological concentrations [218]. In the dynamic phase of obesity this mechanism fails, although leptin levels increase proportionally to weight gain [219]. Thus, "something" overrides the homeostatic function of leptin. However, this does not occur for all individuals and this heterogeneity suggests that there are vulnerability factors to this environmentally-induced impaired leptin function in EH. Hitherto, administrating leptin to obese humans without leptin deficiency has resulted only in modest weight loss [220-224]. Actually, leptin replacement exerts a significant physiological effect only when circulating leptin levels are low [225]. Correspondingly, it has been found that leptin administration inhibited all the changes observed after DIWL: decreased levels of TEE [226], increased skeletal muscle work efficiency, decreased nREE and SNS activity [227], reduced satiation [151], hyper-response to visual cues [228]. Altogether, this suggests that leptin would not only be an afferent hormonal intermediate in a WAT-CNS axis leading to reduce El via its action on homeostatic (ARC, LH, VMH, PVN) and 
non-homeostatic (VTA, NAcc, amygdala) brain areas, but also act in a loop with the SNS as an efferent pathway [229], adding endogenous substrate availability, notably FFA.

\subsection{Insulin}

The role of insulin in energy homeostasis must be considered differently in periphery (i.e., vascular, muscular and visceral) and in the CNS (more specifically the areas involved in EH). In periphery, its classic effects on glucose uptake by insulin-dependent tissues lead to hypoglycemia, hunger, and El, increasing the number of meals for low doses and both size and number for the highest doses [230]. On the opposite, infusing insulin intravenously to rats during a nocturnal fast led to reduced EI on the subsequent day and this was interpreted as a centrally effect of insulin reducing intake [231]. It had actually been shown that insulin stimulated the GE neurons in the VMH in presence of glucose, but inhibited them when administrated alone, whereas on LH, insulin increased neuron activity in a dose-dependent relation [232]. Further studies clarified this action. Insulin stimulates the GE neurons in the ARC when glucose levels are low, leading to decreased release of orexigenic neurotransmitters and therefore reduces intake, and has no effect when glucose levels are elevated [184]. Insulin receptors are expressed in POMC neurons and insulin administration enhances POMC synthesis [233], and therefore reduces El and increases EE. Moreover, insulin reduces NPY expression [234]. This latter action seems to be essential for EH as shown recently with animal models lacking insulin signaling in NPY neurons [235]. Thus, similarly to leptin, insulin has been considered as an adiposity signal [236]. Note that the cell signaling of insulin and leptin is often common in POMC [237] and NPY [238] neurons. Moreover, insulin was shown to reduce activity of dopamine neurons in the VTA [239] and, again similarly to leptin, at low doses the reward potential of food [240]. Importantly, insulin administration in the mediobasal hypothalamus has been reported to inactivate hormonesensitive lipase and suppresses lipolysis [241], suggesting an efferent action of central insulin in reducing fatty acid disposal for peripheral metabolism probably via a decrease in SNS activity. This led these authors to propose a "Yin and Yang" concept of insulin and leptin opposed actions on the WAT [242].

\subsection{Intestinal hormones}


Several intestinal hormones have been reported to be involved in $\mathrm{EH}$, and more specifically in eating behavior [66]. They have firstly been considered as nutrient censors and to have mainly an action on postprandial satiety [65]. We will constrain our review to cholecystokinin, ghrelin, GLP-1 and PYY, which have shown the most documented involvement in $\mathrm{EH}$.

\subsubsection{Ghrelin}

Ghrelin is a hormonal acylated-protein principally secreted in the stomach [243] sending its afferent messages directly via 1 ) the bloodstream where it crosses the blood-brain barrier [244] and reaches the ARC [245] and 2) the vagal afferent to the NTS [246]. In the ARC, ghrelin stimulates the synthesis of NPY and AgRP [247] and opposes leptin effects in inhibiting POMC neurons [245], consistent with its orexigenic effect [248]. However ghrelin also exerts actions in several brain areas involved in reward such as ventral tegmental area (VTA) and the nucleus accumbens (NAcc) [249], in memory such as the amygdala [250] and the hippocampus [251] and in seeking behavior such as the olfactory bulb [252]. After being described, ghrelin was rapidly proposed as initiating meals [253] and this hypothesis seemed confirmed with subjects spontaneously eating [254]. It was moreover shown that ghrelin decreased satiety (meal frequency) and had no effect on satiation (meal size) [255]. The role in meal initiation was questioned by experiments in rats showing that ghrelin was entrained by habitual meal pattern $[256,257]$ suggesting the importance of conditioning in its observation. The higher postprandial ghrelin levels in individuals who had anticipated a meal [258] and the fact that ingesting food was not even necessary for its postprandial levels to decrease, suggested a strong conditioning involvement [259]. Ghrelin may represent a signal for the anticipation of feeding due to conditioning potential of environmental cues [260], improving the adaptation of El to energy requirements by learning processes based on internal cues, circadian factors and external cues associated with food [261]. Ghrelin could therefore contribute to enhance the power of appetizing human food environment to trigger intake and reduce the IMI. Last, ghrelin may contribute to increase fatty acid storage in adipocytes [262] and decrease fatty acid oxidation [263], by an action on the CNS, hypothetically mediated by the SNS [262].

\subsubsection{CCK}


CCK is a peptide hormone secreted by the upper intestine (duodenum and jejunum) in different amounts according to macronutrient composition [264,265]. It is released in bloodstream as soon as $10 \mathrm{~min}$ after eating onset and peaks at $60 \mathrm{~min}$ [266], remaining elevated until 7 hours [267]. CCK is present in various forms (with 8, 22, 33, 39 and 58 amino acids) all sharing a same heptapeptide carboxyl terminus supposed to carry the bioactivity [268]. The octapeptide CCK8 was the most often used in experiments. The anorexigenic role of CCK via satiation (meal size) was documented long ago [269] as was the fact that CCK33 but not CCK8 increased satiety (IMI) [269]. In the brain, CCK binds to CCK-A and -B receptors [270] and exerts actions in 6 hypothalamic and 2 hindbrain (DMN and NTS) sites [271]. Its anorexigenic effect requires the integrity of the vagal pathway [272]. CCK8 was also shown to inhibit the orexigenic effect of ghrelin though its action in the ARC [273] and to more than two-fold increase the insulin transport in the brain [274]. However in overweight and obese individual, CCK8/33 increase was not associated with any alteration in meal size either after a high-CHO or a high-fat meal [265]. Importantly, CCK58 is the most abundant in humans [275] and was found to also increase satiation and satiety whereas CCK8 only altered satiation $[276,277]$.

\subsubsection{GLP-1}

GLP-1 belongs to the incretins family $[278,279]$ and is released prostprandially by the small intestine and the colon, with great differences according to the nutrient content of the meal [280] and in particular glucose [281]. It binds to GLP-1 receptors in various brain regions such as the ARC, the NTS, and the PVN, resulting in decreased El, notably through its effect on the $\mathrm{CRH}$ [282]. This anorexigenic effect has been described either with intracerebroventricular [283] or peripheral [284] administration. The effect with peripheral administration seems to require the vagal afferent [285]. Its kinetics is characterized by a short early phase (10-15 $\mathrm{min}$ ) followed by a longer second phase $(30-60 \mathrm{~min})$ [281]. The main role of GLP-1 is to increase glucose-induced insulin secretion [286]. This may lead to modulate the PPGDinduced meal initiation but this has never been explored. Its effect on El was documented with a reduced satiation at the meal following administration [287] but the effect is much more potent when administrated with PYY [288].

\subsubsection{PYY}


PYY, and more specifically its endogenous isoform $\mathrm{PYY}_{3-36}$, is also released postprandially by the lower intestine (distal intestine, colon and rectum [289]) and binds to various $Y$ receptors in the hypothalamus, the vague and the brainstem [290]. Its main effect is anorexigenic and has been shown at physiological doses in humans [291]. As for GLP-1, this action requires the integrity of the vagal afferent [285]. This action may be mediated partly by inhibiting NPY secretion with important interaction between them for this effect to be operant [292] as is its additive interaction with GLP-1 [288,293]. Its kinetics, with an appearance at $15 \mathrm{~min}$, a peak at 90 min after meal onset and a prolonged high blood levels until 180 min [289], and its observed effects $[288,293,294]$, are in favor of a role in the next meal satiation more than on satiety, but it may indicate a contribution to the subjective satiety between two meals [294].

\subsection{Leptin and glucose interaction: the glucoadipostatic loop}

From all the elements described above, it seems that an adaptation of the glucoadipostatic hypothesis [194] and the neuro-adipose connection [295] can be proposed. It overlaps these models since the role of glucose is pivotal, but extends their mechanisms to a loop with an efferent axis represented by the SNS activity. The leptin-SNS loop was previously described but without involving eating behavior [242]. Figure 3 is a graphical representation of this loop. Leptin, in enhancing fatty acids disposal released by adipocytes through the stimulation of the SNS activity and the reduction of the glucose-induced insulin secretion, may postpone the PPGD and increase satiety, here considered as the delay before the meal initiation. Moreover, glucose potentiates the stimulating effect of leptin on the ARC neurons. This loop requires a spontaneous eating behavior to operate, a situation rarely satisfied in the social environment of everyday life. Moreover, with time, this mechanism switches to an adaptation of meal size based on conditioning processes and learning. Intestinal hormones may participate to this loop in modulating the interval until the next meal (satiety) and the amount eaten during this meal (satiation) according to the composition and the amount of the previous meal.

\subsection{Modulation of the glucoadipostatic loop by the diurnal rhythms}

As stated in the Introduction, the circadian periodicity of eating behavior was extensively explored by Jacques Le Magnen and his various collaborators. They showed in rats that 
sustained high insulin levels and fat synthesis during their active period were followed by a reduced El during their passive period due to higher lipolysis, fatty acid oxidation, and longer intervals between meals $[17,39,296]$. They even showed that in lean and obese-stable rats, the circadian rhythm was characterized by a high and low glucose tolerance in the active and passive periods, respectively, this being not found in VMH-lesioned rats [297]. This provided a support to the role of SNS in this diurnal metabolic-induced eating behavior pattern. VMH is strongly involved in this phenomenon since its lesion definitively abolished glucose and insulin circadian patterns but only temporarily eating behavior one [298]. All the actors of this glucoadipostatic loop, and more largely, of EH, follow a diurnal rhythm. A circadian clock is situated in the suprachiasmatic nucleus (SCN) [299] and synchronizes circadian oscillators (peripheral clocks) localized in most organs and in every cell. This allows an anticipatory behavior and improves the metabolic efficiency as shown by the obesogenic effects of desynchronization such as in shift work [300], chronic jet lag [301] or even unusual meal patterns like regular breakfast skipping [45]. In rats, an inverse relation between SNS activity and food intake was reported, with a decrease effect of insulin on SNS activity when administrated in the $\mathrm{VMH}$. Interestingly, in the SCN, insulin decreased SNS activity only during the rest period (high SNS activity and low EI) but increased it during the active period (low SNS activity and high El) [302], making of insulin a pivotal actor of this circadian mechanism. This diurnal pattern is essential to maintain EH as shown recently in mice who accumulated fat depots when food was restrained to their rest period even when exercise was added [303].

\section{Conclusions}

Although the concept of homeostasis is not fully adapted to the anticipative characteristics of constant energy disposal, it is still used to describe the adaptation of energy supply to needs. To maintain a persistent EE with intermittent El, the brain relies on a diversity of afferent neuro-hormonal messages with glucose and insulin as modulators. Energy stored in the WAT provides substrates when food is not available or between meals and requires efficient SNS activity. Adaptation of El to changes in food availability or composition relies mainly on the delay between meals before conditioning i.e., learning. Learning processes are based on the association of the energy content of food and its postingestive effects, with hedonic and reward effect acting as an enhancer or moderator. This system is perfectly 
appropriate in the environmental conditions that humans encountered during most their history. However, in contemporary conditions it appears that 1) the sedentary body fails to mobilize fat from the WAT to the level needed, leading to reliance on EI, 2) the social constraints do not authorize satiety i.e., length of the interval until the next meal is initiated, to modulate $\mathrm{El}, 3$ ) the constant availability, abundance and diversity of highly palatable foods overstimulates the hedonic and reward systems and overrides their physiological role, leading to non-homeostatic intake, and 4) the constant variety of foods precludes efficient conditioning of eating behavior to post-ingestive effects and energy supply, 5) sustained high insulin levels impair the re-enter of fatty acids in the metabolism to participate to satiety. A model based on a glucoadipostatic loop seems relevant to the current knowledge about the reactive and anticipative adjustment of $\mathrm{El}$ and its frequent failure to maintain energy stability.

Conflicts of Interest: The authors have no financial disclosures or conflicts of interest. Contributors: DC wrote the manuscript and conceived the illustrations, KC provided the critical revision of the manuscript, conceived and realized the illustrations.

\section{REFERENCES}

[1] Cabanac M. Adjustable set point: to honor Harold T. Hammel. J Appl Physiol 2006;100:133846. doi:10.1152/japplphysiol.01021.2005.

[2] Harris RB. Role of set-point theory in regulation of body weight. FASEB J 1990;4:3310-8.

[3] GBD 2015 Obesity Collaborators, Afshin A, Forouzanfar MH, Reitsma MB, Sur P, Estep K, et al. Health Effects of Overweight and Obesity in 195 Countries over 25 Years. N Engl J Med 2017;377:1327. doi:10.1056/NEJMoa1614362.

[4] Schwartz MW, Woods SC, Seeley RJ, Barsh GS, Baskin DG, Leibel RL. Is the energy homeostasis system inherently biased toward weight gain? Diabetes 2003;52:232-8.

[5] Holmes FL. Claude Bernard, The "Milieu Intérieur", and Regulatory Physiology. History and Philosophy of the Life Sciences 1986;8:3-25.

[6] Cannon WB. Organization for physiological homeostasis. Physiological Reviews 1929;9:399431. doi:10.1152/physrev.1929.9.3.399.

[7] Woods SC, Ramsay DS. Homeostasis: Beyond Curt Richter1. Appetite 2007;49:388-98. doi:10.1016/j.appet.2006.09.015.

[8] Sauvant D. [Systematic modelling in nutrition]. Reprod Nutr Dev 1992;32:217-30. 
[9] Keesey RE, Corbett SW. Metabolic defense of the body weight set-point. Res Publ Assoc Res Nerv Ment Dis 1984;62:87-96.

[10] Kennedy GC. The role of depot fat in the hypothalamic control of food intake in the rat. Proc R Soc Lond, B, Biol Sci 1953;140:578-96.

[11] Parameswaran SV, Steffens AB, Hervey GR, de Ruiter L. Involvement of a humoral factor in regulation of body weight in parabiotic rats. American Journal of Physiology-Regulatory, Integrative and Comparative Physiology 1977;232:R150-7. doi:10.1152/ajpregu.1977.232.5.R150.

[12] Faust IM, Johnson PR, Hirsch J. Surgical removal of adipose tissue alters feeding behavior and the development of obesity in rats. Science 1977;197:393-6. doi:10.1126/science.877564.

[13] Faust IM, Johnson PR, Hirsch J. Noncompensation of adipose mass in partially lipectomized mice and rats. Am J Physiol 1976;231:539-44.

[14] Faust IM, Johnson PR, Hirsch J. Adipose tissue regeneration following lipectomy. Science 1977;197:391-3.

[15] Harris RBS, Hausman DB, Bartness TJ. Compensation for partial lipectomy in mice with genetic alterations of leptin and its receptor subtypes. American Journal of Physiology-Regulatory, Integrative and Comparative Physiology 2002;283:R1094-103. doi:10.1152/ajpregu.00339.2002.

[16] Mauer MM, Harris RB, Bartness TJ. The regulation of total body fat: lessons learned from lipectomy studies. Neurosci Biobehav Rev 2001;25:15-28.

[17] Le Magnen J, Devos M, Gaudillière JP, Louis-Sylvestre J, Tallon S. Role of a lipostatic mechanism in regulation by feeding of energy balance in rats. J Comp Physiol Psychol 1973;84:1-23.

[18] Flatt JP. Use and storage of carbohydrate and fat. Am J Clin Nutr 1995;61:952S-959S. doi:10.1093/ajcn/61.4.952S.

[19] Chhabra KH, Adams JM, Jones GL, Yamashita M, Schlapschy M, Skerra A, et al. Reprogramming the body weight set point by a reciprocal interaction of hypothalamic leptin sensitivity and Pomc gene expression reverts extreme obesity. Mol Metab 2016;5:869-81. doi:10.1016/j.molmet.2016.07.012.

[20] Sterling P. Allostasis: A model of predictive regulation. Physiology \& Behavior 2012;106:5-15. doi:10.1016/j.physbeh.2011.06.004.

[21] Moore-Ede MC. Physiology of the circadian timing system: predictive versus reactive homeostasis. American Journal of Physiology-Regulatory, Integrative and Comparative Physiology 1986;250:R737-52. doi:10.1152/ajpregu.1986.250.5.R737.

[22] Jarvandi S, Thibault L, Booth DA. Rats learn to eat more to avoid hunger. Q J Exp Psychol (Hove) 2009;62:663-72. doi:10.1080/17470210802426858.

[23] Le Magnen J, Julien N. Experimental analysis of an anticipatory appetite (first published in French in 1959). Appetite 1999;33:40-2. doi:10.1006/appe.1999.0259.

[24] Booth DA. Hunger and satiety as conditioned reflexes. Res Publ Assoc Res Nerv Ment Dis 1981;59:143-63.

[25] Woods SC, Ramsay DS. Pavlovian influences over food and drug intake. Behav Brain Res 2000;110:175-82. 
[26] Ishii Y, Blundell JE, Halford JCG, Rodgers RJ. Effects of systematic variation in presatiation and fasting on the behavioural satiety sequence in male rats. Physiology \& Behavior 2003;79:227-38. doi:10.1016/S0031-9384(03)00066-0.

[27] Martire SI, Holmes N, Westbrook RF, Morris MJ. Altered Feeding Patterns in Rats Exposed to a Palatable Cafeteria Diet: Increased Snacking and Its Implications for Development of Obesity. PLOS ONE 2013;8:e60407. doi:10.1371/journal.pone.0060407.

[28] Chapelot D, Marmonier C, Aubert R, Gausseres N, Louis-Sylvestre J. A role for glucose and insulin preprandial profiles to differentiate meals and snacks. Physiology \& Behavior 2004;80:721-31. doi:10.1016/j.physbeh.2003.12.006.

[29] Chapelot D. The role of snacking in energy balance: a biobehavioral approach. J Nutr 2011;141:158-62. doi:10.3945/jn.109.114330.

[30] Shomaker LB, Tanofsky-Kraff M, Zocca JM, Courville A, Kozlosky M, Columbo KM, et al. Eating in the absence of hunger in adolescents: intake after a large-array meal compared with that after a standardized meal. Am J Clin Nutr 2010;92:697-703. doi:10.3945/ajcn.2010.29812.

[31] Feig EH, Piers AD, Kral TVE, Lowe MR. Eating in the absence of hunger is related to loss-ofcontrol eating, hedonic hunger, and short-term weight gain in normal-weight women. Appetite 2018;123:317-24. doi:10.1016/j.appet.2018.01.013.

[32] Drummond S, Crombie N, Kirk T. A critique of the effects of snacking on body weight status. Eur J Clin Nutr 1996;50:779-83.

[33] Njike VY, Smith TM, Shuval O, Shuval K, Edshteyn I, Kalantari V, et al. Snack Food, Satiety, and Weight123. Adv Nutr 2016;7:866-78. doi:10.3945/an.115.009340.

[34] Murakami K, Livingstone MBE. Eating Frequency Is Positively Associated with Overweight and Central Obesity in U.S. Adults. J Nutr 2015;145:2715-24. doi:10.3945/jn.115.219808.

[35] Gregori D, Foltran F, Ghidina M, Berchialla P. Understanding the influence of the snack definition on the association between snacking and obesity: a review. Int J Food Sci Nutr 2011;62:270-5. doi:10.3109/09637486.2010.530597.

[36] Marmonier C, Chapelot D, Louis-Sylvestre J. Metabolic and behavioral consequences of a snack consumed in a satiety state. Am J Clin Nutr 1999;70:854-66. doi:10.1093/ajcn/70.5.854.

[37] Marmonier C, Chapelot D, Louis-Sylvestre J. Effects of macronutrient content and energy density of snacks consumed in a satiety state on the onset of the next meal. Appetite 2000;34:161-8. doi:10.1006/appe.1999.0302.

[38] Weingarten HP. Conditioned cues elicit feeding in sated rats: a role for learning in meal initiation. Science 1983;220:431-3.

[39] Le Magnen J. Control of eating behaviour. Baillieres Clin Gastroenterol 1988;2:169-82.

[40] Almiron-Roig E, Palla L, Guest K, Ricchiuti C, Vint N, Jebb SA, et al. Factors that determine energy compensation: a systematic review of preload studies. Nutr Rev 2013;71:458-73.

doi:10.1111/nure.12048.

[41] Rogers PJ, Blundell JE. Meal patterns and food selection during the development of obesity in rats fed a cafeteria diet. Neurosci Biobehav Rev 1984;8:441-53. 
[42] Farley C, Cook JA, Spar BD, Austin TM, Kowalski TJ. Meal pattern analysis of diet-induced obesity in susceptible and resistant rats. Obes Res 2003;11:845-51. doi:10.1038/oby.2003.116.

[43] Chapelot D, Marmonier C, Aubert R, Allègre C, Gausseres N, Fantino M, et al. Consequence of omitting or adding a meal in man on body composition, food intake, and metabolism. Obesity (Silver Spring) 2006;14:215-27. doi:10.1038/oby.2006.28.

[44] Fábry P, Tepperman J. Meal frequency--a possible factor in human pathology. Am J Clin Nutr 1970;23:1059-68. doi:10.1093/ajcn/23.8.1059.

[45] Ma Y, Bertone ER, Stanek EJ, Reed GW, Hebert JR, Cohen NL, et al. Association between eating patterns and obesity in a free-living US adult population. Am J Epidemiol 2003;158:85-92.

[46] Westerterp-Plantenga MS, Kovacs EMR, Melanson KJ. Habitual meal frequency and energy intake regulation in partially temporally isolated men. Int J Obes Relat Metab Disord 2002;26:102-10. doi:10.1038/sj.ijo.0801855.

[47] Yannakoulia M, Melistas L, Solomou E, Yiannakouris N. Association of eating frequency with body fatness in pre- and postmenopausal women. Obesity (Silver Spring) 2007;15:100-6. doi:10.1038/oby.2007.503.

[48] Schoenfeld BJ, Aragon AA, Krieger JW. Effects of meal frequency on weight loss and body composition: a meta-analysis. Nutr Rev 2015;73:69-82. doi:10.1093/nutrit/nuu017.

[49] Himaya A, Fantino M, Antoine JM, Brondel L, Louis-Sylvestre J. Satiety power of dietary fat: a new appraisal. Am J Clin Nutr 1997;65:1410-8. doi:10.1093/ajcn/65.5.1410.

[50] Van Wymelbeke V, Himaya A, Louis-Sylvestre J, Fantino M. Influence of medium-chain and long-chain triacylglycerols on the control of food intake in men. Am J Clin Nutr 1998;68:226-34. doi:10.1093/ajen/68.2.226.

[51] Gatta B, Zuberbuehler C, Arnold M, Aubert R, Langhans W, Chapelot D. Acute effects of pharmacological modifications of fatty acid metabolism on human satiety. British Journal of Nutrition 2008;101:1867-77. doi:10.1017/S0007114508143604.

[52] Chokkalingam K, Jewell K, Norton L, Littlewood J, van Loon LC, Mansell P, et al. High-fat/lowcarbohydrate diet reduces insulin-stimulated carbohydrate oxidation but stimulates nonoxidative glucose disposal in humans: An important role for skeletal muscle pyruvate dehydrogenase kinase 4. J Clin Endocrinol Metab 2007;92:284-92. doi:10.1210/jc.2006-1592.

[53] Randle PJ. Regulatory interactions between lipids and carbohydrates: the glucose fatty acid cycle after 35 years. Diabetes Metab Rev 1998;14:263-83.

[54] Hue L, Taegtmeyer H. The Randle cycle revisited: a new head for an old hat. Am J Physiol Endocrinol Metab 2009;297:E578-591. doi:10.1152/ajpendo.00093.2009.

[55] Jéquier E. Effect of lipid oxidation on glucose utilization in humans. Am J Clin Nutr 1998;67:527S-530S. doi:10.1093/ajcn/67.3.527S.

[56] Gao Q, Horvath TL. Neuronal control of energy homeostasis. FEBS Lett 2008;582:132-41. doi:10.1016/j.febslet.2007.11.063.

[57] Gavrieli A, Mantzoros CS. Novel Molecules Regulating Energy Homeostasis: Physiology and Regulation by Macronutrient Intake and Weight Loss. Endocrinol Metab (Seoul) 2016;31:361-72. doi:10.3803/EnM.2016.31.3.361. 
[58] Lancha A, Frühbeck G, Gómez-Ambrosi J. Peripheral signalling involved in energy homeostasis control. Nutr Res Rev 2012;25:223-48. doi:10.1017/S0954422412000145.

[59] Triantafyllou GA, Paschou SA, Mantzoros CS. Leptin and Hormones: Energy Homeostasis. Endocrinology and Metabolism Clinics of North America 2016;45:633-45. doi:10.1016/j.ecl.2016.04.012.

[60] Lee B, Shao J. Adiponectin and energy homeostasis. Rev Endocr Metab Disord 2014;15:14956. doi:10.1007/s11154-013-9283-3.

[61] Dodd GT, Tiganis T. Insulin action in the brain: Roles in energy and glucose homeostasis. J Neuroendocrinol 2017;29. doi:10.1111/jne.12513.

[62] Roth JD. Amylin and the regulation of appetite and adiposity: recent advances in receptor signaling, neurobiology and pharmacology. Curr Opin Endocrinol Diabetes Obes 2013;20:8-13. doi:10.1097/MED.0b013e32835b896f.

[63] Khandekar N, Berning BA, Sainsbury A, Lin S. The role of pancreatic polypeptide in the regulation of energy homeostasis. Molecular and Cellular Endocrinology 2015;418:33-41. doi:10.1016/j.mce.2015.06.028.

[64] Marić G, Gazibara T, Zaletel I, Labudović Borović M, Tomanović N, Ćirić M, et al. The role of gut hormones in appetite regulation (review). Acta Physiol Hung 2014;101:395-407. doi:10.1556/APhysiol.101.2014.4.1.

[65] Murphy KG, Dhillo WS, Bloom SR. Gut Peptides in the Regulation of Food Intake and Energy Homeostasis. Endocr Rev 2006;27:719-27. doi:10.1210/er.2006-0028.

[66] Roth CL, Doyle RP. Just a Gut Feeling: Central Nervous Effects of Peripheral Gastrointestinal Hormones. Developmental Biology of Gastrointestinal Hormones 2017;32:100-23.

doi:10.1159/000475734.

[67] Yanagi S, Sato T, Kangawa K, Nakazato M. The Homeostatic Force of Ghrelin. Cell Metab 2018;27:786-804. doi:10.1016/j.cmet.2018.02.008.

[68] de Lartigue G, Diepenbroek C. Novel developments in vagal afferent nutrient sensing and its role in energy homeostasis. Curr Opin Pharmacol 2016;31:38-43. doi:10.1016/j.coph.2016.08.007.

[69] Williams G, Harrold JA, Cutler DJ. The hypothalamus and the regulation of energy homeostasis: lifting the lid on a black box. Proceedings of the Nutrition Society 2000;59:385-96. doi:10.1017/S0029665100000434.

[70] Sohn J-W. Network of hypothalamic neurons that control appetite. BMB Rep 2015;48:22933.

[71] Joly-Amado A, Cansell C, Denis RGP, Delbes A-S, Castel J, Martinez S, et al. The hypothalamic arcuate nucleus and the control of peripheral substrates. Best Pract Res Clin Endocrinol Metab 2014;28:725-37. doi:10.1016/j.beem.2014.03.003.

[72] Ollmann MM, Wilson BD, Yang YK, Kerns JA, Chen Y, Gantz I, et al. Antagonism of central melanocortin receptors in vitro and in vivo by agouti-related protein. Science 1997;278:135-8.

[73] King BM. The rise, fall, and resurrection of the ventromedial hypothalamus in the regulation of feeding behavior and body weight. Physiology \& Behavior 2006;87:221-44.

doi:10.1016/j.physbeh.2005.10.007. 
[74] Sakaguchi T, Arase K, Bray GA. Sympathetic activity and food intake of rats with ventromedial hypothalamic lesions. Int J Obes 1988;12:285-91.

[75] Grill HJ, Hayes MR. The nucleus tractus solitarius: a portal for visceral afferent signal processing, energy status assessment and integration of their combined effects on food intake. Int J Obes (Lond) 2009;33 Suppl 1:S11-15. doi:10.1038/ijo.2009.10.

[76] Grill HJ, Hayes MR. Hindbrain Neurons as an Essential Hub in the Neuroanatomically Distributed Control of Energy Balance. Cell Metab 2012;16:296-309.

doi:10.1016/j.cmet.2012.06.015.

[77] Liu S, Borgland SL. Regulation of the mesolimbic dopamine circuit by feeding peptides. Neuroscience 2015;289:19-42. doi:10.1016/j.neuroscience.2014.12.046.

[78] Smith KS, Berridge KC. The ventral pallidum and hedonic reward: neurochemical maps of sucrose "liking" and food intake. J Neurosci 2005;25:8637-49. doi:10.1523/JNEUROSCI.190205.2005.

[79] Peciña S, Berridge KC. Hedonic hot spot in nucleus accumbens shell: where do mu-opioids cause increased hedonic impact of sweetness? J Neurosci 2005;25:11777-86.

doi:10.1523/JNEUROSCI.2329-05.2005.

[80] Nogueiras R, Romero-Picó A, Vazquez MJ, Novelle MG, López M, Diéguez C. The opioid system and food intake: homeostatic and hedonic mechanisms. Obes Facts 2012;5:196-207. doi:10.1159/000338163.

[81] Berridge KC. "Liking" and "wanting" food rewards: brain substrates and roles in eating disorders. Physiol Behav 2009;97:537-50. doi:10.1016/j.physbeh.2009.02.044.

[82] Castro DC, Cole SL, Berridge KC. Lateral hypothalamus, nucleus accumbens, and ventral pallidum roles in eating and hunger: interactions between homeostatic and reward circuitry. Front Syst Neurosci 2015;9:90. doi:10.3389/fnsys.2015.00090.

[83] Petrovich GD, Gallagher M. Amygdala subsystems and control of feeding behavior by learned cues. Ann N Y Acad Sci 2003;985:251-62.

[84] Richard D. Cognitive and autonomic determinants of energy homeostasis in obesity. Nat Rev Endocrinol 2015;11:489-501. doi:10.1038/nrendo.2015.103.

[85] Vainik U, Dagher A, Dubé L, Fellows LK. Neurobehavioural correlates of body mass index and eating behaviours in adults: a systematic review. Neurosci Biobehav Rev 2013;37:279-99.

doi:10.1016/j.neubiorev.2012.11.008.

[86] Cone JJ, McCutcheon JE, Roitman MF. Ghrelin acts as an interface between physiological state and phasic dopamine signaling. J Neurosci 2014;34:4905-13. doi:10.1523/JNEUROSCI.440413.2014 .

[87] Mietlicki-Baase EG, Reiner DJ, Cone JJ, Olivos DR, McGrath LE, Zimmer DJ, et al. Amylin modulates the mesolimbic dopamine system to control energy balance. Neuropsychopharmacology 2015;40:372-85. doi:10.1038/npp.2014.180.

[88] Bray GA. Reciprocal relation between the sympathetic nervous system and food intake. Brain Res Bull 1991;27:517-20.

[89] Mayer J, Thomas DW. Regulation of food intake and obesity. Science 1967;156:328-37. 
[90] Mayer J, Marshall NB, Vitale JJ, Christensen JH, Mashayekhi MB, Stare FJ. Exercise, food intake and body weight in normal rats and genetically obese adult mice. Am J Physiol 1954;177:5448. doi:10.1152/ajplegacy.1954.177.3.544.

[91] Melzer K, Kayser B, Saris WHM, Pichard C. Effects of physical activity on food intake. Clinical Nutrition 2005;24:885-95. doi:10.1016/j.clnu.2005.06.003.

[92] Saris WHM, Blair SN, van Baak MA, Eaton SB, Davies PSW, Di Pietro L, et al. How much physical activity is enough to prevent unhealthy weight gain? Outcome of the IASO 1st Stock Conference and consensus statement. Obes Rev 2003;4:101-14.

[93] Wareham NJ, van Sluijs EMF, Ekelund U. Physical activity and obesity prevention: a review of the current evidence. Proc Nutr Soc 2005;64:229-47.

[94] Swift DL, Johannsen NM, Lavie CJ, Earnest CP, Church TS. The Role of Exercise and Physical Activity in Weight Loss and Maintenance. Prog Cardiovasc Dis 2014;56:441-7. doi:10.1016/j.pcad.2013.09.012.

[95] Miller CT, Fraser SF, Levinger I, Straznicky NE, Dixon JB, Reynolds J, et al. The effects of exercise training in addition to energy restriction on functional capacities and body composition in obese adults during weight loss: a systematic review. PLOS ONE 2013;8:e81692. doi:10.1371/journal.pone.0081692.

[96] Segal KR, Xavier Pi-Sunyer F. Exercise and Obesity. Medical Clinics of North America 1989;73:217-36. doi:10.1016/S0025-7125(16)30700-3.

[97] Psota T, Chen KY. Measuring energy expenditure in clinical populations: rewards and challenges. Eur J Clin Nutr 2013;67:436-42. doi:10.1038/ejcn.2013.38.

[98] Tremblay A, Nadeau A, Després JP, St-Jean L, Thériault G, Bouchard C. Long-term exercise training with constant energy intake. 2: Effect on glucose metabolism and resting energy expenditure. Int J Obes 1990;14:75-84.

[99] Horowitz JF. Exercise-induced alterations in muscle lipid metabolism improve insulin sensitivity. Exerc Sport Sci Rev 2007;35:192-6. doi:10.1097/jes.0b013e318156e084.

[100] Hunter GR, Fisher G, Neumeier WH, Carter SJ, Plaisance EP. Exercise Training and Energy Expenditure following Weight Loss. Med Sci Sports Exerc 2015;47:1950-7. doi:10.1249/MSS.0000000000000622.

[101] Thompson D, Karpe F, Lafontan M, Frayn K. Physical activity and exercise in the regulation of human adipose tissue physiology. Physiol Rev 2012;92:157-91. doi:10.1152/physrev.00012.2011.

[102] Davy KP, Orr JS. Sympathetic nervous system behavior in human obesity. Neurosci Biobehav Rev 2009;33:116-24. doi:10.1016/j.neubiorev.2008.05.024.

[103] Krzentowski G, Pirnay F, Luyckx AS, Pallikarakis N, Lacroix M, Mosora F, et al. Metabolic adaptations in post-exercise recovery. Clin Physiol 1982;2:277-88.

[104] Elder SJ, Roberts SB. The effects of exercise on food intake and body fatness: a summary of published studies. Nutr Rev 2007;65:1-19.

[105] Schubert MM, Desbrow B, Sabapathy S, Leveritt M. Acute exercise and subsequent energy intake. A meta-analysis. Appetite 2013;63:92-104. doi:10.1016/j.appet.2012.12.010. 
[106] Schubert MM, Sabapathy S, Leveritt M, Desbrow B. Acute exercise and hormones related to appetite regulation: a meta-analysis. Sports Med 2014;44:387-403. doi:10.1007/s40279-013-0120-3.

[107] Mani BK, Castorena CM, Osborne-Lawrence S, Vijayaraghavan P, Metzger NP, Elmquist JK, et al. Ghrelin mediates exercise endurance and the feeding response post-exercise. Mol Metab 2018;9:114-30. doi:10.1016/j.molmet.2018.01.006.

[108] King JA, Wasse LK, Stensel DJ, Nimmo MA. Exercise and ghrelin. A narrative overview of research. Appetite 2013;68:83-91. doi:10.1016/j.appet.2013.04.018.

[109] King JA, Wasse LK, Stensel DJ. Acute exercise increases feeding latency in healthy normal weight young males but does not alter energy intake. Appetite 2013;61:45-51.

doi:10.1016/j.appet.2012.10.018.

[110] King NA, Burley VJ, Blundell JE. Exercise-induced suppression of appetite: effects on food intake and implications for energy balance. Eur J Clin Nutr 1994;48:715-24.

[111] King NA, Blundell JE. High-fat foods overcome the energy expenditure induced by highintensity cycling or running. Eur J Clin Nutr 1995;49:114-23.

[112] Charlot K, Pichon A, Chapelot D. Exercise prior to a freely requested meal modifies pre and postprandial glucose profile, substrate oxidation and sympathovagal balance. Nutr Metab (Lond) 2011;8:66. doi:10.1186/1743-7075-8-66.

[113] Saris WH. Effects of energy restriction and exercise on the sympathetic nervous system. Int J Obes Relat Metab Disord 1995;19 Suppl 7:S17-23.

[114] Zouhal H, Lemoine-Morel S, Mathieu M-E, Casazza GA, Jabbour G. Catecholamines and obesity: effects of exercise and training. Sports Med 2013;43:591-600. doi:10.1007/s40279-0130039-8.

[115] Mickelsen O, Takahashi S, Craig C. Experimental obesity. I. Production of obesity in rats by feeding high-fat diets. J Nutr 1955;57:541-54. doi:10.1093/jn/57.4.541.

[116] Sclafani A, Springer D. Dietary obesity in adult rats: Similarities to hypothalamic and human obesity syndromes. Physiology \& Behavior 1976;17:461-71. doi:10.1016/0031-9384(76)90109-8.

[117] Schemmel R, Mickelsen O, Gill JL. Dietary obesity in rats: Body weight and body fat accretion in seven strains of rats. J Nutr 1970;100:1041-8. doi:10.1093/jn/100.9.1041.

[118] Levin BE, Dunn-Meynell AA, Balkan B, Keesey RE. Selective breeding for diet-induced obesity and resistance in Sprague-Dawley rats. American Journal of Physiology-Regulatory, Integrative and Comparative Physiology 1997;273:R725-30. doi:10.1152/ajpregu.1997.273.2.R725.

[119] Levin BE, Triscari J, Sullivan AC. Relationship between sympathetic activity and diet-induced obesity in two rat strains. American Journal of Physiology-Regulatory, Integrative and Comparative Physiology 1983;245:R364-71. doi:10.1152/ajpregu.1983.245.3.R364.

[120] Treit D, Spetch ML, Deutsch JA. Variety in the flavor of food enhances eating in the rat: a controlled demonstration. Physiol Behav 1983;30:207-11.

[121] South T, Holmes NM, Martire SI, Westbrook RF, Morris MJ. Rats Eat a Cafeteria-Style Diet to Excess but Eat Smaller Amounts and Less Frequently when Tested with Chow. PLoS One 2014;9. doi:10.1371/journal.pone.0093506. 
[122] Louis-Sylvestre J, Giachetti I, Le Magnen J. Sensory versus dietary factors in cafeteria-induced overweight. Physiol Behav 1984;32:901-5.

[123] Brondel L, Romer M, Van Wymelbeke V, Pineau N, Jiang T, Hanus C, et al. Variety enhances food intake in humans: role of sensory-specific satiety. Physiol Behav 2009;97:44-51. doi:10.1016/j.physbeh.2009.01.019.

[124] Rolls BJ. Experimental analyses of the effects of variety in a meal on human feeding. Am J Clin Nutr 1985;42:932-9. doi:10.1093/ajcn/42.5.932.

[125] Johnson F, Wardle J. Variety, palatability, and obesity. Adv Nutr 2014;5:851-9. doi:10.3945/an.114.007120.

[126] Berthoud H-R. Homeostatic and non-homeostatic pathways involved in the control of food intake and energy balance. Obesity (Silver Spring) 2006;14 Suppl 5:197S-200S.

doi:10.1038/oby.2006.308.

[127] Berthoud H-R. Metabolic and hedonic drives in the neural control of appetite: who is the boss? Current Opinion in Neurobiology 2011;21:888-96. doi:10.1016/j.conb.2011.09.004.

[128] la Fleur SE, Luijendijk MCM, van der Zwaal EM, Brans M a. D, Adan R a. H. The snacking rat as model of human obesity: effects of a free-choice high-fat high-sugar diet on meal patterns. Int J Obes (Lond) 2014;38:643-9. doi:10.1038/ijo.2013.159.

[129] Chang S, Graham B, Yakubu F, Lin D, Peters JC, Hill JO. Metabolic differences between obesity-prone and obesity-resistant rats. Am J Physiol 1990;259:R1103-1110.

doi:10.1152/ajpregu.1990.259.6.R1103.

[130] Pagliassotti MJ, Knobel SM, Shahrokhi KA, Manzo AM, Hill JO. Time course of adaptation to a high-fat diet in obesity-resistant and obesity-prone rats. Am J Physiol 1994;267:R659-664. doi:10.1152/ajpregu.1994.267.3.R659.

[131] Giroux V, Saidj S, Simon C, Laville M, Segrestin B, Mathieu M-E. Physical activity, energy expenditure and sedentary parameters in overfeeding studies - a systematic review. BMC Public Health 2018;18. doi:10.1186/s12889-018-5801-2.

[132] Klein S, Goran M. Energy metabolism in response to overfeeding in young adult men. Metab Clin Exp 1993;42:1201-5.

[133] Levine JA, Eberhardt NL, Jensen MD. Role of nonexercise activity thermogenesis in resistance to fat gain in humans. Science 1999;283:212-4.

[134] Apolzan JW, Bray GA, Smith SR, de Jonge L, Rood J, Han H, et al. Effects of weight gain induced by controlled overfeeding on physical activity. Am J Physiol Endocrinol Metab 2014;307:E1030-7. doi:10.1152/ajpendo.00386.2014.

[135] He J, Votruba S, Pomeroy J, Bonfiglio S, Krakoff J. Measurement of Ad Libitum Food Intake, Physical Activity, and Sedentary Time in Response to Overfeeding. PLoS One 2012;7. doi:10.1371/journal.pone.0036225.

[136] Pasquet $P$, Apfelbaum M. Recovery of initial body weight and composition after long-term massive overfeeding in men. Am J Clin Nutr 1994;60:861-3. doi:10.1093/ajcn/60.6.861.

[137] Roberts SB, Young VR, Fuss P, Fiatarone MA, Richard B, Rasmussen H, et al. Energy expenditure and subsequent nutrient intakes in overfed young men. American Journal of Physiology- 
Regulatory, Integrative and Comparative Physiology 1990;259:R461-9. doi:10.1152/ajpregu.1990.259.3.R461.

[138] Tappy L. Metabolic consequences of overfeeding in humans. Curr Opin Clin Nutr Metab Care 2004;7:623-8.

[139] Tsai AG, Wadden TA. Systematic review: an evaluation of major commercial weight loss programs in the United States. Ann Intern Med 2005;142:56-66.

[140] Weiss EC, Galuska DA, Kettel Khan L, Gillespie C, Serdula MK. Weight Regain in U.S. Adults Who Experienced Substantial Weight Loss, 1999-2002. American Journal of Preventive Medicine 2007;33:34-40. doi:10.1016/j.amepre.2007.02.040.

[141] Thomas JG, Bond DS, Phelan S, Hill JO, Wing RR. Weight-Loss Maintenance for 10 Years in the National Weight Control Registry. American Journal of Preventive Medicine 2014;46:17-23. doi:10.1016/j.amepre.2013.08.019.

[142] Wing RR, Phelan S. Long-term weight loss maintenance. Am J Clin Nutr 2005;82:222S-225S. doi:10.1093/ajcn/82.1.222S.

[143] Ramage S, Farmer A, Eccles KA, McCargar L. Healthy strategies for successful weight loss and weight maintenance: a systematic review. Appl Physiol Nutr Metab 2014;39:1-20.

doi:10.1139/apnm-2013-0026.

[144] Tremblay A, Chaput J-P. Adaptive reduction in thermogenesis and resistance to lose fat in obese men. Br J Nutr 2009;102:488-92. doi:10.1017/S0007114508207245.

[145] Goele K, Bosy-Westphal A, Rumcker B, Lagerpusch M, Muller MJ. Influence of changes in body composition and adaptive thermogenesis on the difference between measured and predicted weight loss in obese women. Obes Facts 2009;2:105-9. doi:10.1159/000210369.

[146] Leibel RL, Rosenbaum M, Hirsch J. Changes in energy expenditure resulting from altered body weight. N Engl J Med 1995;332:621-8. doi:10.1056/NEJM199503093321001.

[147] Rosenbaum M, Vandenborne K, Goldsmith R, Simoneau J-A, Heymsfield S, Joanisse DR, et al. Effects of experimental weight perturbation on skeletal muscle work efficiency in human subjects. American Journal of Physiology-Regulatory, Integrative and Comparative Physiology 2003;285:R18392. doi:10.1152/ajpregu.00474.2002.

[148] Goldsmith R, Joanisse DR, Gallagher D, Pavlovich K, Shamoon E, Leibel RL, et al. Effects of experimental weight perturbation on skeletal muscle work efficiency, fuel utilization, and biochemistry in human subjects. Am J Physiol Regul Integr Comp Physiol 2010;298:R79-88. doi:10.1152/ajpregu.00053.2009.

[149] Baldwin KM, Joanisse DR, Haddad F, Goldsmith RL, Gallagher D, Pavlovich KH, et al. Effects of weight loss and leptin on skeletal muscle in human subjects. Am J Physiol Regul Integr Comp Physiol 2011;301:R1259-66. doi:10.1152/ajpregu.00397.2011.

[150] Almundarij TI, Gavini CK, Novak CM. Suppressed sympathetic outflow to skeletal muscle, muscle thermogenesis, and activity energy expenditure with calorie restriction. Physiol Rep 2017;5. doi:10.14814/phy2.13171. 
[151] Kissileff HR, Thornton JC, Torres MI, Pavlovich K, Mayer LS, Kalari V, et al. Leptin reverses declines in satiation in weight-reduced obese humans123. Am J Clin Nutr 2012;95:309-17. doi:10.3945/ajen.111.012385.

[152] Booth DA, Lee M, McAleavey C. Acquired sensory control of satiation in man. Br J Psychol 1976;67:137-47.

[153] Toubro S, Astrup A. Randomised comparison of diets for maintaining obese subjects' weight after major weight loss: ad lib, low fat, high carbohydrate diet $v$ fixed energy intake. BMJ 1997;314:29-34.

[154] Wang X, Lyles MF, You T, Berry MJ, Rejeski WJ, Nicklas BJ. Weight regain is related to decreases in physical activity during weight loss. Med Sci Sports Exerc 2008;40:1781-8. doi:10.1249/MSS.0b013e31817d8176.

[155] Jakicic JM, Marcus BH, Gallagher KI, Napolitano M, Lang W. Effect of exercise duration and intensity on weight loss in overweight, sedentary women: a randomized trial. JAMA 2003;290:132330. doi:10.1001/jama.290.10.1323.

[156] Foright RM, Presby DM, Sherk VD, Kahn D, Checkley LA, Giles ED, et al. Is regular exercise an effective strategy for weight loss maintenance? Physiol Behav 2018;188:86-93.

doi:10.1016/j.physbeh.2018.01.025.

[157] Landsberg L, Young JB. The role of the sympathetic nervous system and catecholamines in the regulation of energy metabolism. Am J Clin Nutr 1983;38:1018-24. doi:10.1093/ajcn/38.6.1018.

[158] Seoane-Collazo P, Fern $\varnothing$ J, Gonzalez F, Diéguez C, Leis R, Nogueiras R, et al. Hypothalamicautonomic control of energy homeostasis. Endocrine 2015;50:276-91. doi:10.1007/s12020-0150658-y.

[159] Bamshad M, Aoki VT, Adkison MG, Warren WS, Bartness TJ. Central nervous system origins of the sympathetic nervous system outflow to white adipose tissue. Am J Physiol 1998;275:R291-299.

[160] Youngstrom TG, Bartness TJ. Catecholaminergic innervation of white adipose tissue in Siberian hamsters. Am J Physiol 1995;268:R744-751. doi:10.1152/ajpregu.1995.268.3.R744.

[161] Bowers RR, Festuccia WTL, Song CK, Shi H, Migliorini RH, Bartness TJ. Sympathetic innervation of white adipose tissue and its regulation of fat cell number. Am J Physiol Regul Integr Comp Physiol 2004;286:R1167-1175. doi:10.1152/ajpregu.00558.2003.

[162] Nguyen NLT, Randall J, Banfield BW, Bartness TJ. Central sympathetic innervations to visceral and subcutaneous white adipose tissue. Am J Physiol Regul Integr Comp Physiol 2014;306:R375-386. doi:10.1152/ajpregu.00552.2013.

[163] Guarino D, Nannipieri M, lervasi G, Taddei S, Bruno RM. The Role of the Autonomic Nervous System in the Pathophysiology of Obesity. Front Physiol 2017;8. doi:10.3389/fphys.2017.00665.

[164] Spraul M, Ravussin E, Fontvieille AM, Rising R, Larson DE, Anderson EA. Reduced sympathetic nervous activity. A potential mechanism predisposing to body weight gain. J Clin Invest 1993;92:1730-5. doi:10.1172/JCl116760.

[165] Tataranni PA, Young JB, Bogardus C, Ravussin E. A low sympathoadrenal activity is associated with body weight gain and development of central adiposity in Pima Indian men. Obes Res 1997;5:341-7. 
[166] Bray GA. Obesity, a disorder of nutrient partitioning: the MONA LISA hypothesis. J Nutr 1991;121:1146-62. doi:10.1093/jn/121.8.1146.

[167] Grassi G, Seravalle G, Cattaneo BM, Bolla GB, Lanfranchi A, Colombo M, et al. Sympathetic activation in obese normotensive subjects. Hypertension 1995;25:560-3.

[168] Gentile CL, Orr JS, Davy BM, Davy KP. Modest weight gain is associated with sympathetic neural activation in nonobese humans. Am J Physiol Regul Integr Comp Physiol 2007;292:R18341838. doi:10.1152/ajpregu.00876.2006.

[169] Coppack SW, Horowitz JF, Paramore DS, Cryer PE, Royal HD, Klein S. Whole body, adipose tissue, and forearm norepinephrine kinetics in lean and obese women. Am J Physiol 1998;275:E830834.

[170] Jocken JWE, Goossens GH, van Hees AMJ, Frayn KN, van Baak M, Stegen J, et al. Effect of beta-adrenergic stimulation on whole-body and abdominal subcutaneous adipose tissue lipolysis in lean and obese men. Diabetologia 2008;51:320-7. doi:10.1007/s00125-007-0866-y.

[171] Ito K, Dezaki K, Yoshida M, Yamada H, Miura R, Rita RS, et al. Endogenous a2AAdrenoceptor-Operated Sympathoadrenergic Tones Attenuate Insulin Secretion via cAMP/TRPM2 Signaling. Diabetes 2017;66:699-709. doi:10.2337/db16-1166.

[172] Cruciani-Guglielmacci C, Vincent-Lamon M, Rouch C, Orosco M, Ktorza A, Magnan C. Early changes in insulin secretion and action induced by high-fat diet are related to a decreased sympathetic tone. Am J Physiol Endocrinol Metab 2005;288:E148-154. doi:10.1152/ajpendo.00225.2004.

[173] Mayer J. Regulation of energy intake and the body weight: the glucostatic theory and the lipostatic hypothesis. Ann N Y Acad Sci 1955;63:15-43.

[174] Louis-Sylvestre J, Le Magnen J. Fall in blood glucose level precedes meal onset in free-feeding rats. Neurosci Biobehav Rev 1980;4 Suppl 1:13-5.

[175] Melanson KJ, Westerterp-Plantenga MS, Saris WH, Smith FJ, Campfield LA. Blood glucose patterns and appetite in time-blinded humans: carbohydrate versus fat. Am J Physiol 1999;277:R337345.

[176] Campfield LA, Smith FJ. Blood glucose dynamics and control of meal initiation: a pattern detection and recognition theory. Physiol Rev 2003;83:25-58. doi:10.1152/physrev.00019.2002.

[177] Oomura Y, Ooyama H, Sugimori M, Nakamura T, Yamada Y. Glucose inhibition of the glucosesensitive neurone in the rat lateral hypothalamus. Nature 1974;247:284-6.

[178] Oomura Y, Yoshimatsu H. Neural network of glucose monitoring system. Journal of the Autonomic Nervous System 1984;10:359-72. doi:10.1016/0165-1838(84)90033-X.

[179] Aou S, Oomura Y, Le'na'rd L, Nishino H, Inokuchi A, Minami T, et al. Behavioral significance of monkey hypothalamic glucose-sensitive neurons. Brain Research 1984;302:69-74. doi:10.1016/00068993(84)91285-X.

[180] Katafuchi T, Oomura Y, Yoshimatsu H. Single neuron activity in the rat lateral hypothalamus during 2-deoxy-d-glucose induced and natural feeding behavior. Brain Research 1985;359:1-9. doi:10.1016/0006-8993(85)91406-4. 
[181] Burdakov D, González JA. Physiological functions of glucose-inhibited neurones. Acta Physiol (Oxf) 2009;195:71-8. doi:10.1111/j.1748-1716.2008.01922.x.

[182] Ibrahim N, Bosch MA, Smart JL, Qiu J, Rubinstein M, Rønnekleiv OK, et al. Hypothalamic proopiomelanocortin neurons are glucose responsive and express K(ATP) channels. Endocrinology 2003;144:1331-40. doi:10.1210/en.2002-221033.

[183] Muroya S, Funahashi H, Yamanaka A, Kohno D, Uramura K, Nambu T, et al. Orexins (hypocretins) directly interact with neuropeptide $\mathrm{Y}, \mathrm{POMC}$ and glucose-responsive neurons to regulate Ca 2+ signaling in a reciprocal manner to leptin: orexigenic neuronal pathways in the mediobasal hypothalamus. Eur J Neurosci 2004;19:1524-34. doi:10.1111/j.1460-9568.2004.03255.x.

[184] Wang R, Liu X, Hentges ST, Dunn-Meynell AA, Levin BE, Wang W, et al. The regulation of glucose-excited neurons in the hypothalamic arcuate nucleus by glucose and feeding-relevant peptides. Diabetes 2004;53:1959-65.

[185] Routh VH. Glucose Sensing Neurons in the Ventromedial Hypothalamus. Sensors (Basel) 2010;10:9002-25. doi:10.3390/s101009002.

[186] Mayer CH, Fink H, Rex A, Voigt J-P. Changes in extracellular hypothalamic glucose in relation to feeding. Eur J Neurosci 2006;24:1695-701. doi:10.1111/j.1460-9568.2006.05042.x.

[187] Mountjoy PD, Bailey SJ, Rutter GA. Inhibition by glucose or leptin of hypothalamic neurons expressing neuropeptide $\mathrm{Y}$ requires changes in AMP-activated protein kinase activity. Diabetologia 2007;50:168-77. doi:10.1007/s00125-006-0473-3.

[188] Cai XJ, Widdowson PS, Harrold J, Wilson S, Buckingham RE, Arch JR, et al. Hypothalamic orexin expression: modulation by blood glucose and feeding. Diabetes 1999;48:2132-7.

doi:10.2337/diabetes.48.11.2132.

[189] Dunn-Meynell AA, Routh VH, Kang L, Gaspers L, Levin BE. Glucokinase is the likely mediator of glucosensing in both glucose-excited and glucose-inhibited central neurons. Diabetes 2002;51:2056-65.

[190] Mountjoy PD, Rutter GA. Glucose sensing by hypothalamic neurones and pancreatic islet cells: AMPle evidence for common mechanisms? Experimental Physiology 2007;92:311-9.

doi:10.1113/expphysiol.2006.036004.

[191] Thorin D, Golay A, Simonson DC, Jéquier E, Felber JP, DeFronzo RA. The effect of selective beta adrenergic blockade on glucose-induced thermogenesis in man. Metabolism - Clinical and Experimental 1986;35:524-8. doi:10.1016/0026-0495(86)90009-0.

[192] Levin BE, Govek EK, Dunn-Meynell AA. Reduced glucose-induced neuronal activation in the hypothalamus of diet-induced obese rats. Brain Res 1998;808:317-9.

[193] Matsuda M, Liu Y, Mahankali S, Pu Y, Mahankali A, Wang J, et al. Altered hypothalamic function in response to glucose ingestion in obese humans. Diabetes 1999;48:1801-6.

[194] Mobbs CV, Isoda F, Makimura H, Mastaitis J, Mizuno T, Shu I-W, et al. Impaired glucose signaling as a cause of obesity and the metabolic syndrome: the glucoadipostatic hypothesis. Physiol Behav 2005;85:3-23. doi:10.1016/j.physbeh.2005.04.005.

[195] Zhang Y, Proenca R, Maffei M, Barone M, Leopold L, Friedman JM. Positional cloning of the mouse obese gene and its human homologue. Nature 1994;372:425-32. doi:10.1038/372425a0. 
[196] Rentsch J, Levens N, Chiesi M. Recombinant ob-gene product reduces food intake in fasted mice. Biochem Biophys Res Commun 1995;214:131-6. doi:10.1006/bbrc.1995.2266.

[197] Zorrilla EP, Inoue K, Valdez GR, Tabarin A, Koob GF. Leptin and post-prandial satiety: acute central leptin more potently reduces meal frequency than meal size in the rat. Psychopharmacology (Berl) 2005;177:324-35. doi:10.1007/s00213-004-1952-1.

[198] Jéquier E. Leptin signaling, adiposity, and energy balance. Ann N Y Acad Sci 2002;967:379-88.

[199] Park H-K, Ahima RS. Physiology of leptin: energy homeostasis, neuroendocrine function and metabolism. Metabolism 2015;64:24-34. doi:10.1016/j.metabol.2014.08.004.

[200] Rosenbaum M, Leibel RL. Role of leptin in energy homeostasis in humans. J Endocrinol 2014;223:T83-96. doi:10.1530/JOE-14-0358.

[201] Elmquist JK. Hypothalamic pathways underlying the endocrine, autonomic, and behavioral effects of leptin. Physiol Behav 2001;74:703-8.

[202] Ahima RS, Kelly J, Elmquist JK, Flier JS. Distinct Physiologic and Neuronal Responses to Decreased Leptin and Mild Hyperleptinemia. Endocrinology 1999;140:4923-31.

doi:10.1210/endo.140.11.7105.

[203] López M, Seoane L, García MC, Lago F, Casanueva FF, Señarís R, et al. Leptin regulation of prepro-orexin and orexin receptor mRNA levels in the hypothalamus. Biochem Biophys Res Commun 2000;269:41-5. doi:10.1006/bbrc.2000.2245.

[204] Kim KW, Sohn J-W, Kohno D, Xu Y, Williams K, Elmquist JK. SF-1 in the Ventral Medial Hypothalamic Nucleus: A Key Regulator of Homeostasis. Mol Cell Endocrinol 2011;336:219-23. doi:10.1016/j.mce.2010.11.019.

[205] Garfield AS, Patterson C, Skora S, Gribble FM, Reimann F, Evans ML, et al. Neurochemical Characterization of Body Weight-Regulating Leptin Receptor Neurons in the Nucleus of the Solitary Tract. Endocrinology 2012;153:4600-7. doi:10.1210/en.2012-1282.

[206] Farooqi IS, Bullmore E, Keogh J, Gillard J, O'Rahilly S, Fletcher PC. Leptin regulates striatal regions and human eating behavior. Science 2007;317:1355. doi:10.1126/science.1144599.

[207] Hommel JD, Trinko R, Sears RM, Georgescu D, Liu Z-W, Gao X-B, et al. Leptin receptor signaling in midbrain dopamine neurons regulates feeding. Neuron 2006;51:801-10.

doi:10.1016/j.neuron.2006.08.023.

[208] Leinninger GM, Jo Y-H, Leshan RL, Louis GW, Yang H, Barrera JG, et al. Leptin acts via leptin receptor-expressing lateral hypothalamic neurons to modulate the mesolimbic dopamine system and suppress feeding. Cell Metab 2009;10:89-98. doi:10.1016/j.cmet.2009.06.011.

[209] Billes SK, Simonds SE, Cowley MA. Leptin reduces food intake via a dopamine D2 receptordependent mechanism. Mol Metab 2012;1:86-93. doi:10.1016/j.molmet.2012.07.003.

[210] van der Plasse G, van Zessen R, Luijendijk MCM, Erkan H, Stuber GD, Ramakers GMJ, et al. Modulation of cue-induced firing of ventral tegmental area dopamine neurons by leptin and ghrelin. Int J Obes (Lond) 2015;39:1742-9. doi:10.1038/ijo.2015.131.

[211] Holsen LM, Jackson B. Reward Capacity Predicts Leptin Dynamics During LaboratoryControlled Eating in Women as a Function of Body Mass Index. Obesity (Silver Spring) 2017;25:15648. doi:10.1002/oby.21930. 
[212] Yamanaka A, Beuckmann CT, Willie JT, Hara J, Tsujino N, Mieda M, et al. Hypothalamic orexin neurons regulate arousal according to energy balance in mice. Neuron 2003;38:701-13.

[213] Leinninger GM, Opland DM, Jo Y-H, Faouzi M, Christensen L, Cappellucci LA, et al. Leptin action via neurotensin neurons controls orexin, the mesolimbic dopamine system and energy balance. Cell Metab 2011;14:313-23. doi:10.1016/j.cmet.2011.06.016.

[214] Dunbar JC, Hu Y, Lu H. Intracerebroventricular leptin increases lumbar and renal sympathetic nerve activity and blood pressure in normal rats. Diabetes 1997;46:2040-3.

[215] Pandit R, Beerens S, Adan R a. H. Role of leptin in energy expenditure: the hypothalamic perspective. Am J Physiol Regul Integr Comp Physiol 2017;312:R938-47. doi:10.1152/ajpregu.00045.2016.

[216] Emilsson V, Liu YL, Cawthorne MA, Morton NM, Davenport M. Expression of the functional leptin receptor $m R N A$ in pancreatic islets and direct inhibitory action of leptin on insulin secretion. Diabetes 1997;46:313-6.

[217] Mizuno A, Murakami T, Otani S, Kuwajima M, Shima K. Leptin affects pancreatic endocrine functions through the sympathetic nervous system. Endocrinology 1998;139:3863-70. doi:10.1210/endo.139.9.6201.

[218] Cases JA, Gabriely I, Ma XH, Yang XM, Michaeli T, Fleischer N, et al. Physiological increase in plasma leptin markedly inhibits insulin secretion in vivo. Diabetes 2001;50:348-52.

[219] Chu NF, Spiegelman D, Yu J, Rifai N, Hotamisligil GS, Rimm EB. Plasma leptin concentrations and four-year weight gain among US men. Int J Obes Relat Metab Disord 2001;25:346-53. doi:10.1038/sj.ijo.0801549.

[220] Strehler KYE, Matheny M, Kirichenko N, Sakarya Y, Bruce E, Toklu HZ, et al. Onset of leptin resistance shows temporal differences related to dose or pulsed treatment. Eur J Pharmacol 2016;779:177-85. doi:10.1016/j.ejphar.2016.03.026.

[221] Ravussin E, Smith SR, Mitchell JA, Shringarpure R, Shan K, Maier H, et al. Enhanced Weight Loss With Pramlintide/Metreleptin: An Integrated Neurohormonal Approach to Obesity Pharmacotherapy. Obesity (Silver Spring) 2009;17:1736-43. doi:10.1038/oby.2009.184.

[222] Heymsfield SB, Greenberg AS, Fujioka K, Dixon RM, Kushner R, Hunt T, et al. Recombinant Leptin for Weight Loss in Obese and Lean Adults: A Randomized, Controlled, Dose-Escalation Trial. JAMA 1999;282:1568-75. doi:10.1001/jama.282.16.1568.

[223] Moon H-S, Matarese G, Brennan AM, Chamberland JP, Liu X, Fiorenza CG, et al. Efficacy of Metreleptin in Obese Patients With Type 2 Diabetes: Cellular and Molecular Pathways Underlying Leptin Tolerance. Diabetes 2011;60:1647-56. doi:10.2337/db10-1791.

[224] Zelissen PMJ, Stenlof K, Lean MEJ, Fogteloo J, Keulen ETP, Wilding J, et al. Effect of three treatment schedules of recombinant methionyl human leptin on body weight in obese adults: a randomized, placebo-controlled trial. Diabetes Obes Metab 2005;7:755-61. doi:10.1111/j.14631326.2005.00468.x.

[225] Mantzoros CS, Magkos F, Brinkoetter M, Sienkiewicz E, Dardeno TA, Kim S-Y, et al. Leptin in human physiology and pathophysiology. Am J Physiol Endocrinol Metab 2011;301:E567-84.

doi:10.1152/ajpendo.00315.2011. 
[226] Rosenbaum M, Murphy EM, Heymsfield SB, Matthews DE, Leibel RL. Low dose leptin administration reverses effects of sustained weight-reduction on energy expenditure and circulating concentrations of thyroid hormones. J Clin Endocrinol Metab 2002;87:2391-4. doi:10.1210/jcem.87.5.8628.

[227] Rosenbaum M, Goldsmith R, Bloomfield D, Magnano A, Weimer L, Heymsfield S, et al. Lowdose leptin reverses skeletal muscle, autonomic, and neuroendocrine adaptations to maintenance of reduced weight. J Clin Invest 2005;115:3579-86. doi:10.1172/JCI25977.

[228] Rosenbaum M, Sy M, Pavlovich K, Leibel RL, Hirsch J. Leptin reverses weight loss-induced changes in regional neural activity responses to visual food stimuli. J Clin Invest 2008;118:2583-91. doi:10.1172/JCl35055.

[229] Harris RBS. Direct and indirect effects of leptin on adipocyte metabolism. Biochim Biophys Acta 2014;1842:414-23. doi:10.1016/j.bbadis.2013.05.009.

[230] Larue-Achagiotis C, Le Magnen J. The different effects of continuous night and day-time insulin infusion on the meal pattern of normal rats: Comparison with the meal pattern of hyperphagic hypothalamic rats. Physiology \& Behavior 1979;22:435-9. doi:10.1016/00319384(79)90005-2.

[231] Larue-Achagiotis C, Le Magnen J. Insulin infusion during a nocturnal fast suppresses the subsequent day-time intake. Physiology \& Behavior 1984;33:719-22. doi:10.1016/00319384(84)90037-4.

[232] Oomura $\mathrm{Y}$, Kita H. Insulin acting as a modulator of feeding through the hypothalamus. Diabetologia 1981;20 Suppl:290-8.

[233] Benoit SC, Air EL, Coolen LM, Strauss R, Jackman A, Clegg DJ, et al. The Catabolic Action of Insulin in the Brain Is Mediated by Melanocortins. J Neurosci 2002;22:9048-52.

doi:10.1523/JNEUROSCI.22-20-09048.2002.

[234] Schwartz MW, Marks JL, Sipolst AJ, Basking DG, Woods SC, Kahn SE, et al. CENTRAL INSULIN ADMINISTRATION REDUCES NEUROPEPTIDE Y MRNA EXPRESSION IN THE ARCUATE NUCLEUS OF FOOD-DEPRIVED LEAN (Fa/Fa) BUT NOT OBESE (fa/fa) ZUCKER RATS. Endocrinology 1991;128:26457. doi:10.1210/endo-128-5-2645.

[235] Loh K, Zhang L, Brandon A, Wang Q, Begg D, Qi Y, et al. Insulin controls food intake and energy balance via NPY neurons. Mol Metab 2017;6:574-84. doi:10.1016/j.molmet.2017.03.013.

[236] Baskin DG, Figlewicz Lattemann D, Seeley RJ, Woods SC, Porte D, Schwartz MW. Insulin and leptin: dual adiposity signals to the brain for the regulation of food intake and body weight. Brain Res 1999;848:114-23.

[237] Qiu J, Wagner EJ, Rønnekleiv OK, Kelly MJ. Insulin and leptin excite anorexigenic proopiomelanocortin neurones via activation of TRPC5 channels. Journal of Neuroendocrinology 2018;30:e12501. doi:10.1111/jne.12501.

[238] Yang M-J, Wang F, Wang J-H, Wu W-N, Hu Z-L, Cheng J, et al. PI3K integrates the effects of insulin and leptin on large-conductance $\mathrm{Ca} 2+$-activated $\mathrm{K}+$ channels in neuropeptide $\mathrm{Y}$ neurons of the hypothalamic arcuate nucleus. American Journal of Physiology-Endocrinology and Metabolism 2009;298:E193-201. doi:10.1152/ajpendo.00155.2009. 
[239] Mebel DM, Wong JCY, Dong YJ, Borgland SL. Insulin in the ventral tegmental area reduces hedonic feeding and suppresses dopamine concentration via increased reuptake. Eur J Neurosci 2012;36:2336-46. doi:10.1111/j.1460-9568.2012.08168.x.

[240] Bruijnzeel AW, Corrie LW, Rogers JA, Yamada H. Effects of insulin and leptin in the ventral tegmental area and arcuate hypothalamic nucleus on food intake and brain reward function in female rats. Behav Brain Res 2011;219:254-64. doi:10.1016/j.bbr.2011.01.020.

[241] Scherer T, O'Hare J, Diggs-Andrews K, Schweiger M, Cheng B, Lindtner C, et al. Brain insulin controls adipose tissue lipolysis and lipogenesis. Cell Metab 2011;13:183-94. doi:10.1016/j.cmet.2011.01.008.

[242] Scherer T, Buettner C. Yin and Yang of hypothalamic insulin and leptin signaling in regulating white adipose tissue metabolism. Rev Endocr Metab Disord 2011;12:235-43. doi:10.1007/s11154011-9190-4.

[243] Kojima M, Hosoda H, Date Y, Nakazato M, Matsuo H, Kangawa K. Ghrelin is a growthhormone-releasing acylated peptide from stomach. Nature 1999;402:656-60. doi:10.1038/45230.

[244] Banks WA, Tschöp M, Robinson SM, Heiman ML. Extent and Direction of Ghrelin Transport Across the Blood-Brain Barrier Is Determined by Its Unique Primary Structure. J Pharmacol Exp Ther 2002;302:822-7. doi:10.1124/jpet.102.034827.

[245] Riediger T, Traebert M, Schmid HA, Scheel C, Lutz TA, Scharrer E. Site-specific effects of ghrelin on the neuronal activity in the hypothalamic arcuate nucleus. Neuroscience Letters 2003;341:151-5. doi:10.1016/\$0304-3940(02)01381-2.

[246] Date Y, Murakami N, Toshinai K, Matsukura S, Niijima A, Matsuo H, et al. The role of the gastric afferent vagal nerve in ghrelin-induced feeding and growth hormone secretion in rats. Gastroenterology 2002;123:1120-8. doi:10.1053/gast.2002.35954.

[247] Wang L, Saint-Pierre DH, Taché Y. Peripheral ghrelin selectively increases Fos expression in neuropeptide $\mathrm{Y}$ - synthesizing neurons in mouse hypothalamic arcuate nucleus. Neuroscience Letters 2002;325:47-51. doi:10.1016/S0304-3940(02)00241-0.

[248] Wren AM, Small CJ, Ward HL, Murphy KG, Dakin CL, Taheri S, et al. The Novel Hypothalamic Peptide Ghrelin Stimulates Food Intake and Growth Hormone Secretion. Endocrinology 2000;141:4325-8. doi:10.1210/endo.141.11.7873.

[249] Skibicka KP, Hansson C, Alvarez-Crespo M, Friberg PA, Dickson SL. Ghrelin directly targets the ventral tegmental area to increase food motivation. Neuroscience 2011;180:129-37. doi:10.1016/j.neuroscience.2011.02.016.

[250] Alvarez-Crespo M, Skibicka KP, Farkas I, Molnár CS, Egecioglu E, Hrabovszky E, et al. The Amygdala as a Neurobiological Target for Ghrelin in Rats: Neuroanatomical, Electrophysiological and Behavioral Evidence. PLoS One 2012;7. doi:10.1371/journal.pone.0046321.

[251] Kanoski SE, Fortin SM, Ricks KM, Grill HJ. Ghrelin signaling in the ventral hippocampus stimulates learned and motivational aspects of feeding via PI3K-Akt signaling. Biol Psychiatry 2013;73:915-23. doi:10.1016/j.biopsych.2012.07.002.

[252] Rhea EM, Salameh TS, Gray S, Niu J, Banks WA, Tong J. Ghrelin transport across the bloodbrain barrier can occur independently of the growth hormone secretagogue receptor. Molecular Metabolism 2018. doi:10.1016/j.molmet.2018.09.007. 
[253] Cummings DE, Purnell JQ, Frayo RS, Schmidova K, Wisse BE, Weigle DS. A preprandial rise in plasma ghrelin levels suggests a role in meal initiation in humans. Diabetes 2001;50:1714-9.

[254] Cummings DE, Frayo RS, Marmonier C, Aubert R, Chapelot D. Plasma ghrelin levels and hunger scores in humans initiating meals voluntarily without time- and food-related cues. Am J Physiol Endocrinol Metab 2004;287:E297-304. doi:10.1152/ajpendo.00582.2003.

[255] Teuffel P, Wang L, Prinz P, Goebel-Stengel M, Scharner S, Kobelt P, et al. Treatment with the ghrelin-O-acyltransferase (GOAT) inhibitor GO-COA-Tat reduces food intake by reducing meal frequency in rats. J Physiol Pharmacol 2015;66:493-503.

[256] Drazen DL, Vahl TP, D’Alessio DA, Seeley RJ, Woods SC. Effects of a fixed meal pattern on ghrelin secretion: evidence for a learned response independent of nutrient status. Endocrinology 2006;147:23-30. doi:10.1210/en.2005-0973.

[257] Frecka JM, Mattes RD. Possible entrainment of ghrelin to habitual meal patterns in humans. American Journal of Physiology-Gastrointestinal and Liver Physiology 2008;294:G699-707. doi:10.1152/ajpgi.00448.2007.

[258] Ott V, Friedrich M, Zemlin J, Lehnert H, Schultes B, Born J, et al. Meal anticipation potentiates postprandial ghrelin suppression in humans. Psychoneuroendocrinology 2012;37:1096-100. doi:10.1016/j.psyneuen.2011.10.007.

[259] Arosio M, Ronchi CL, Beck-Peccoz P, Gebbia C, Giavoli C, Cappiello V, et al. Effects of modified sham feeding on ghrelin levels in healthy human subjects. J Clin Endocrinol Metab 2004;89:5101-4. doi:10.1210/jc.2003-032222.

[260] Dailey MJ, Moran TH, Holland PC, Johnson AW. The antagonism of ghrelin alters the appetitive response to learned cues associated with food. Behav Brain Res 2016;303:191-200. doi:10.1016/j.bbr.2016.01.040.

[261] Hsu TM, Suarez AN, Kanoski SE. Ghrelin: A link between memory and ingestive behavior. Physiol Behav 2016;162:10-7. doi:10.1016/j.physbeh.2016.03.039.

[262] Theander-Carrillo C, Wiedmer P, Cettour-Rose P, Nogueiras R, Perez-Tilve D, Pfluger P, et al. Ghrelin action in the brain controls adipocyte metabolism. J Clin Invest 2006;116:1983-93. doi:10.1172/JCI25811.

[263] Velasco C, Librán-Pérez M, Otero-Rodiño C, López-Patiño MA, Míguez JM, Soengas JL. Intracerebroventricular ghrelin treatment affects lipid metabolism in liver of rainbow trout (Oncorhynchus mykiss). General and Comparative Endocrinology 2016;228:33-9. doi:10.1016/j.ygcen.2016.01.016.

[264] Brennan IM, Luscombe-Marsh ND, Seimon RV, Otto B, Horowitz M, Wishart JM, et al. Effects of fat, protein, and carbohydrate and protein load on appetite, plasma cholecystokinin, peptide YY, and ghrelin, and energy intake in lean and obese men. American Journal of PhysiologyGastrointestinal and Liver Physiology 2012;303:G129-40. doi:10.1152/ajpgi.00478.2011.

[265] Gibbons C, Finlayson G, Caudwell P, Webb D-L, Hellström PM, Näslund E, et al. Postprandial profiles of CCK after high fat and high carbohydrate meals and the relationship to satiety in humans. Peptides 2016;77:3-8. doi:10.1016/j.peptides.2015.09.010.

[266] Rehfeld JF. Accurate measurement of cholecystokinin in plasma. Clinical Chemistry 1998;44:991-1001. 
[267] GULLO L, PEZZILLI R, TOMASSETTI P, GIORGIO RD. Plasma cholecystokinin and neurotensin after an ordinary meal in humans. /data/revues/03998320/00220001/25/2008.

[268] Ondetti MA, Rubin B, Engel SL, Pluščec J, Sheehan JT. Cholecystokinin-pancreozymin. Digest Dis Sci 1970;15:149-56. doi:10.1007/BF02235646.

[269] Kraly FS, Carty WJ, Resnick S, Smith GP. Effect of cholecystokinin on meal size and intermeal interval in the sham-feeding rat. J Comp Physiol Psychol 1978;92:697-707.

[270] Moran TH, Robinson PH, Goldrich MS, McHugh PR. Two brain cholecystokinin receptors: implications for behavioral actions. Brain Research 1986;362:175-9. doi:10.1016/00068993(86)91413-7.

[271] Blevins JE, Stanley BG, Reidelberger RD. Brain regions where cholecystokinin suppresses feeding in rats. Brain Research 2000;860:1-10. doi:10.1016/S0006-8993(99)02477-4.

[272] Brown TAL, Washington MC, Metcalf SA, Sayegh Al. The feeding responses evoked by cholecystokinin are mediated by vagus and splanchnic nerves. Peptides 2011;32:1581-6. doi:10.1016/j.peptides.2011.06.024.

[273] Kobelt P, Tebbe JJ, Tjandra I, Stengel A, Bae H-G, Andresen V, et al. CCK inhibits the orexigenic effect of peripheral ghrelin. American Journal of Physiology-Regulatory, Integrative and Comparative Physiology 2005;288:R751-8. doi:10.1152/ajpregu.00094.2004.

[274] May AA, Liu M, Woods SC, Begg DP. CCK increases the transport of insulin into the brain. Physiology \& Behavior 2016;165:392-7. doi:10.1016/j.physbeh.2016.08.025.

[275] Raybould HE, Reeve JR. CCK-58: A novel reagent for studying the regulation of cholecystokinin bioactivity. Peptides 1996;17:1307-11. doi:10.1016/S0196-9781(96)00200-8.

[276] Sayegh Al, Washington MC, Raboin SJ, Aglan AH, Reeve JR. CCK-58 prolongs the intermeal interval, whereas CCK-8 reduces this interval: Not all forms of cholecystokinin have equal bioactivity. Peptides 2014;55:120-5. doi:10.1016/j.peptides.2014.02.014.

[277] Overduin J, Gibbs J, Cummings DE, Reeve JR. CCK-58 Elicits Both Satiety and Satiation in Rats while CCK-8 Elicits Only Satiation. Peptides 2014;54:71-80. doi:10.1016/j.peptides.2014.01.008.

[278] Baggio LL, Drucker DJ. Biology of Incretins: GLP-1 and GIP. Gastroenterology 2007;132:213157. doi:10.1053/j.gastro.2007.03.054.

[279] Wu T, Rayner CK, Jones K, Horowitz M. Dietary effects on incretin hormone secretion. Vitam Horm 2010;84:81-110. doi:10.1016/B978-0-12-381517-0.00003-5.

[280] Brubaker PL. The glucagon-like peptides: pleiotropic regulators of nutrient homeostasis. Ann N Y Acad Sci 2006;1070:10-26. doi:10.1196/annals.1317.006.

[281] Herrmann C, Göke R, Richter G, Fehmann H-C, Arnold R, Göke B. Glucagon-Like Peptide-1 and Glucose-Dependent Insulin-Releasing Polypeptide Plasma Levels in Response to Nutrients. DIG 1995;56:117-26. doi:10.1159/000201231.

[282] Larsen PJ, Tang-Christensen M, Jessop DS. Central Administration of Glucagon-Like Peptide-1 Activates Hypothalamic Neuroendocrine Neurons in the Rat. Endocrinology 1997;138:4445-55.

doi:10.1210/endo.138.10.5270. 
[283] Turton MD, O'Shea D, Gunn I, Beak SA, Edwards CMB, Meeran K, et al. A role for glucagonlike peptide-1 in the central regulation of feeding. Nature 1996;379:69-72. doi:10.1038/379069a0.

[284] Fonseca FR de, Navarro M, Alvarez E, Roncero I, Chowen JA, Maestre O, et al. Peripheral versus central effects of glucagon-like peptide-1 receptor agonists on satiety and body weight loss in Zucker obese rats. Metabolism - Clinical and Experimental 2000;49:709-17. doi:10.1053/meta.2000.6251.

[285] Abbott CR, Monteiro M, Small CJ, Sajedi A, Smith KL, Parkinson JRC, et al. The inhibitory effects of peripheral administration of peptide YY3-36 and glucagon-like peptide-1 on food intake are attenuated by ablation of the vagal-brainstem-hypothalamic pathway. Brain Research 2005;1044:127-31. doi:10.1016/j.brainres.2005.03.011.

[286] Kreymann B, Ghatei MA, Williams G, Bloom SR. GLUCAGON-LIKE PEPTIDE-1 7-36: A PHYSIOLOGICAL INCRETIN IN MAN. The Lancet 1987;330:1300-4. doi:10.1016/S0140-6736(87)911949.

[287] Edwards CMB, Stanley SA, Davis R, Brynes AE, Frost GS, Seal L, et al. Exendin-4 reduces fasting and postprandial glucose and decreases energy intake in healthy volunteers. American Journal of Physiology-Endocrinology and Metabolism 2001;281:E155-61. doi:10.1152/ajpendo.2001.281.1.E155.

[288] De Silva A, Salem V, Long CJ, Makwana A, Newbould RD, Rabiner EA, et al. The Gut Hormones PYY3-36 and GLP-17-36 amide Reduce Food Intake and Modulate Brain Activity in Appetite Centers in Humans. Cell Metab 2011;14:700-6. doi:10.1016/j.cmet.2011.09.010.

[289] Adrian TE, Ferri GL, Bacarese-Hamilton AJ, Fuessl HS, Polak JM, Bloom SR. Human distribution and release of a putative new gut hormone, peptide YY. Gastroenterology 1985;89:1070-7.

[290] Batterham RL, Bloom SR. The Gut Hormone Peptide YY Regulates Appetite. Annals of the New York Academy of Sciences 2003;994:162-8. doi:10.1111/j.1749-6632.2003.tb03176.x.

[291] Batterham RL, Cowley MA, Small CJ, Herzog H, Cohen MA, Dakin CL, et al. Gut hormone PYY ${ }_{36}$ physiologically inhibits food intake. Nature 2002;418:650-4. doi:10.1038/nature00887.

[292] Zhang L, Nguyen AD, Lee I-CJ, Yulyaningsih E, Riepler SJ, Stehrer B, et al. NPY modulates PYY function in the regulation of energy balance and glucose homeostasis. Diabetes, Obesity and Metabolism 2012;14:727-36. doi:10.1111/j.1463-1326.2012.01592.x.

[293] Neary NM, Small CJ, Druce MR, Park AJ, Ellis SM, Semjonous NM, et al. Peptide YY3-36 and Glucagon-Like Peptide-17-36 Inhibit Food Intake Additively. Endocrinology 2005;146:5120-7. doi:10.1210/en.2005-0237.

[294] Degen L, Oesch S, Casanova M, Graf S, Ketterer S, Drewe J, et al. Effect of Peptide YY3-36 on Food Intake in Humans. Gastroenterology 2005;129:1430-6. doi:10.1053/j.gastro.2005.09.001.

[295] Mahú I, Domingos Al. The sympathetic neuro-adipose connection and the control of body weight. Experimental Cell Research 2017;360:27-30. doi:10.1016/j.yexcr.2017.03.047.

[296] Le Magnen J. [Lipogenesis, lipolysis and feeding rhythms]. Ann Endocrinol (Paris) 1988;49:98104. 
[297] Penicaud L, Larue-Achagiotis C, Le Magnen J. Endocrine basis for weight gain after fasting or VMH lesion in rats. American Journal of Physiology-Endocrinology and Metabolism 1983;245:E24652. doi:10.1152/ajpendo.1983.245.3.E246.

[298] Egawa M, Inoue S, Satoh S, Takamura Y, Nagai K, Nakagawa H. Acute and chronic effects of $\mathrm{VMH}$ lesions on orcadian rhythms in food intake and metabolites. Brain Research Bulletin 1993;31:293-9. doi:10.1016/0361-9230(93)90220-6.

[299] Buhr ED, Takahashi JS. Molecular components of the mammalian circadian clock. Handb Exp Pharmacol 2013:3-27. doi:10.1007/978-3-642-25950-0_1.

[300] Antunes LC, Levandovski R, Dantas G, Caumo W, Hidalgo MP. Obesity and shift work: chronobiological aspects. Nutr Res Rev 2010;23:155-68. doi:10.1017/S0954422410000016.

[301] Parsons M, Moffitt T, Gregory A, Goldman-Mellor S, Nolan P, Poulton R, et al. Social jetlag, obesity and metabolic disorder: investigation in a cohort study. Int J Obes (Lond) 2015;39:842-8. doi:10.1038/ijo.2014.201.

[302] Sakaguchi T, Takahashi M, Bray GA. Diurnal changes in sympathetic activity. Relation to food intake and to insulin injected into the ventromedial or suprachiasmatic nucleus. J Clin Invest

1988;82:282-6.

[303] Okauchi H, Hashimoto C, Nakao R, Oishi K. Timing of food intake is more potent than habitual voluntary exercise to prevent diet-induced obesity in mice. Chronobiology International 2018;0:1-18. doi:10.1080/07420528.2018.1516672. 


\section{Legends}

Figure 1. Schematic representation of the 3 components of energy homeostasis: energy intake, energy expenditure and endogenous energy stores. The three group of factors modulating energy stores are described. Note that in this homeostatic model, the anticipative capacity of the allostatic model is missing. CNS, central nervous system; EH, energy homeostasis; PA, physical activity; REE, resting energy expenditure; TEF, thermic effect of food;

Figure 2. Schematic representation of the afferent neuro-hormonal actors and their relations with brain areas involved in energy intake and expenditure. The currently known functions and the main involved neurotransmitters are summarized in the text. ARC, arcuate nucleus; CCK, cholecystokinin; DMH, dorsomedian nucleus; GLP-1, glucagon-like peptide 1; LH, lateral hypothalamus; NAcc, nucleus accumbens; NTS, nucleus tractus solitarius; OXM, oxyntomodulin, PAL, physical activity level; POMC, pro-opiomelanocortin; PP, pancreatic polypeptide; PPGD, preprandial glucose decline; PVN, paraventricular nucleus; REE, resting energy expenditure; SNS, sympathetic nervous system; SF-1, steroidogenic factor 1; SPA, spontaneous physical activity; TEE, total energy expenditure; $\mathrm{VMH}$, ventro-medial hypothalamus; VTA, ventral tegmental area.

Figure 3. The glucoadipostatic loop. Energy intake (EI) has been found to exert its energy homeostastic role by modulating the duration of intermeal intervals (IMI) i.e., satiety. Each meal is preceded and initiated by a preprandial glucose decline (PPGD). (1) If energy was exclusively provided by glucose, the duration of the IMI would only depend upon the glucose absorbed in the duodenum and released by the liver (not shown). (2) The release of free fatty acids by adipocytes adds substrates to total oxidation, spares glucose and delays the PPGD and the onset of the next meal, increasing the duration of the intermeal interval. Glucose-induced insulin secreted in the bloodstream will reduce adipocyte lipolysis and limits the increase of the intermeal interval. (3) Leptin secreted by adipocytes reaches the hypothalamus via the bloodstream, where it stimulates neurons synthetizing anorexigenic neurotransmitters (not shown) and sympathetic nervous activity (SNA). This action is modulated by local glucose levels. The sympathetic nervous system will 1) reduce glucose- 
induced insulin secretion and its inhibiting effect on adipocyte lipolysis, 2) directly stimulate the release of fatty acids by adipocytes, enhancing their contribution to total substrate oxidation and their glucose-sparing effect, leading to increase the intermeal interval. This homeostatic response requires that meals are spontaneously initiated and that no intermeal intake alters the sequence. The anticipation, conditioning and reward processes are therefore possible, based on the postingestive duration of the IMI (satiety) of the food consumed at the meal. 


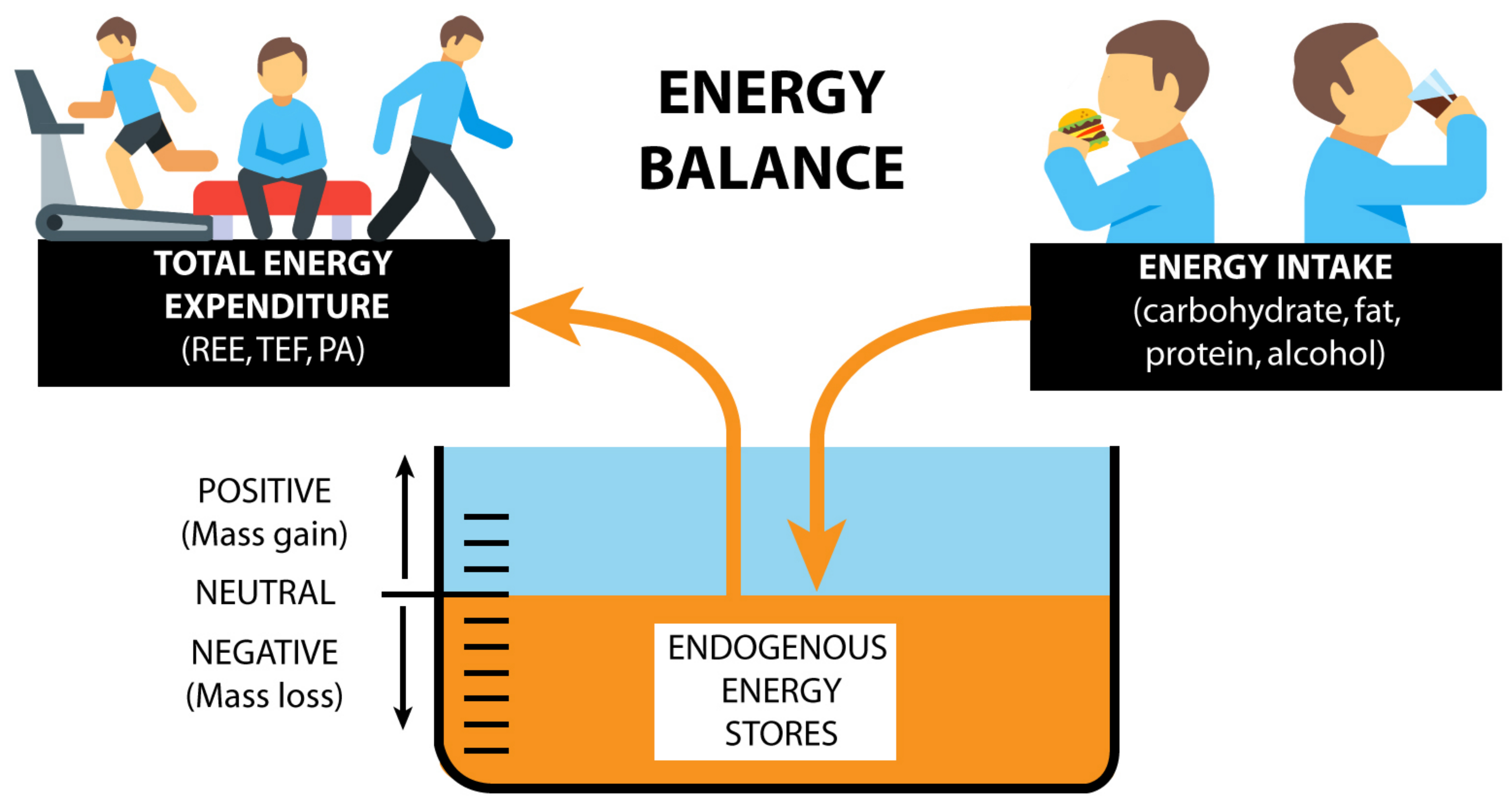

GLUCOSE, HORMONES,
NEUROTRANSMITTERS,
VAGAL NERVES

Afferent modulators of energy homeostasis through the transmission of peripheral messages to the CNS and the translation in 1) eating behavior (energy intake) and 2) thermogenesis and spontaneous physical activity (energy expenditure)

\section{SUBSTRATE \\ OXIDATION}

Adaptative metabolic component of energy homeostasis through oxidative pathways and nutrient partitioning

\section{SYMPATHETIC NERVOUS SYSTEM}

Efferent modulator of energy homeostasis through the neural transmission of CNS messages and the consecutive increased disposal of endogenous energy 


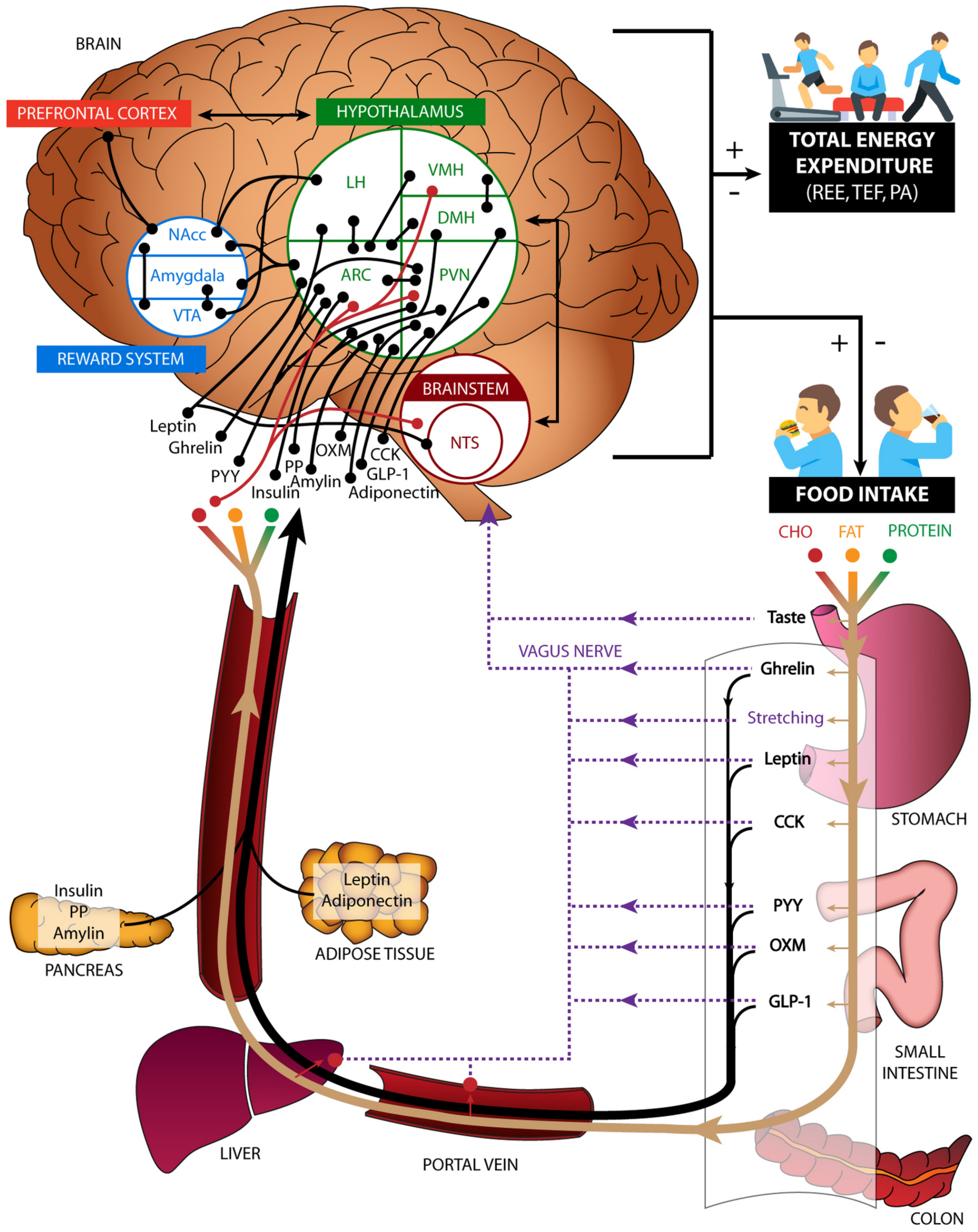




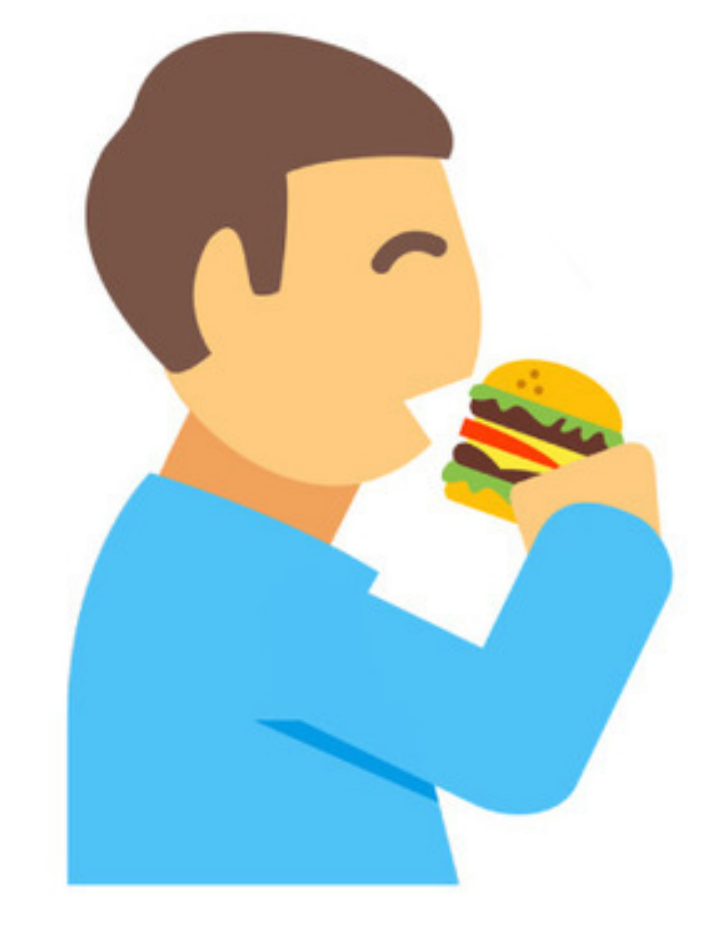

\section{INTERMEAL INTERVAL (SATIETY)}
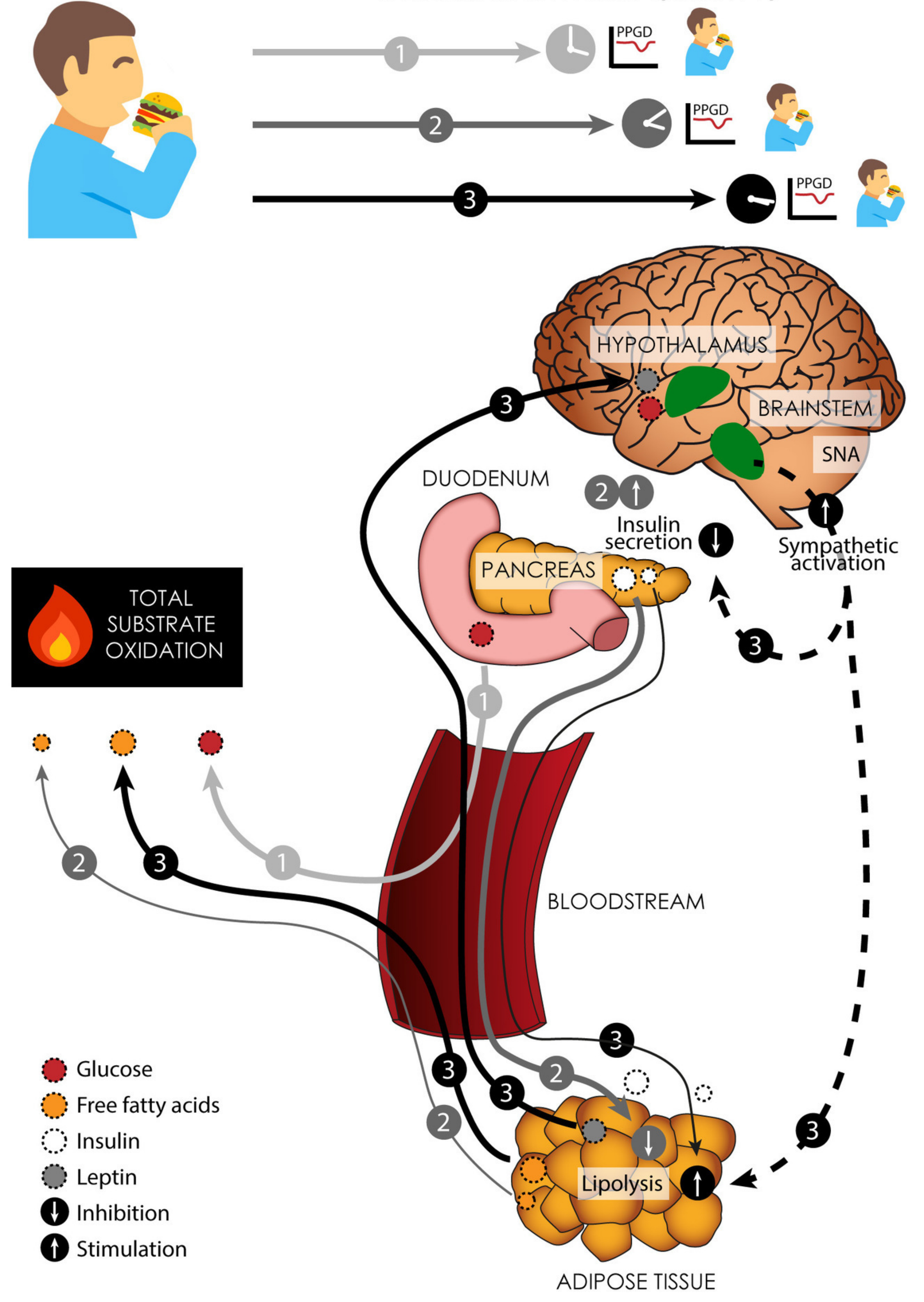